Max-Planck-Institut für demografische Forschung

Max Planck Institute for Demographic Research

Konrad-Zuse-Strasse 1 - D-18057 Rostock - GERMANY

Tel +49 (0) 3812081 - 0; Fax +49 (0) 3812081 - 202;

http://www.demogr.mpg.de

MPIDR WORKING PAPER WP 2009-007

MARCH 2009

\title{
Non-marital Childbearing in Russia: \\ Second Demographic Transition or \\ Pattern of Disadvantage?
}

Brienna Perelli-Harris (perelli@demogr.mpg.de)

Theodore P. Gerber

This working paper has been approved for release by: Joshua R. Goldstein (goldstein@demogr.mpg.de)

Head of the Laboratory of Economic and Social Demography and Head of the Laboratory of

Historical Demography.

(C) Copyright is held by the authors.

Working papers of the Max Planck Institute for Demographic Research receive only limited review. Views or opinions expressed in working papers are attributable to the authors and do not necessarily reflect those of the Institute. 


\title{
Non-marital Childbearing in Russia: Second Demographic Transition or Pattern of Disadvantage?
}

\begin{abstract}
Using retrospective union, birth, and education histories that span 1980-2003, this study investigates nonmarital childbearing in post-Soviet Russia. We employ a combination of methods to decompose fertility rates by union status and analyze the processes that lead to a nonmarital birth. We find that the primary cause of the increase in the proportion of nonmarital births is not due to the changing fertility behavior of cohabitors, nor to changes in union behavior after conception, but due to the increasing proportion of women who cohabit before conception. We also find that the relationship between education and nonmarital childbearing has not changed over time; the least educated women have the highest birth rates within cohabitation and as single mothers, primarily due to a lower probability of legitimating a nonmarital conception. Based on these findings, we argue that Russia has more in common with the pattern of disadvantage in the United States, as opposed to the trends described by the second demographic transition. We also find several aspects of non-marital childbearing that neither of these perspectives anticipates.
\end{abstract}


Many demographers consider non-marital childbearing a definitive characteristic of the "second demographic transition” (Lesthaeghe and Neidert 2006; McLanahan 2004; Sobotka, Zeman, and Kantorová 2003; Surkyn and Lesthaeghe 2004). However, the circumstances leading to and consequences of non-marital childbearing vary greatly depending on context. In Europe, particularly the Scandinavian countries, non-marital childbearing primarily occurs among stable, cohabiting couples (Kiernan 2004). In the United States, however, non-marital childbearing is more often associated with single mothers and low-income minority populations (Wu and Wolfe 2001; Edin and Kefalas 2005). Moreover, the unions of cohabiting couples who have children in the U.S. tend to be less stable than marital unions (Wu and Wolfe 2001). Thus, while non-marital childbearing in Northern Europe signifies a rejection of traditional institutions and an increase in independence and autonomy, non-marital childbearing in the U.S. is associated with the inability to enter and maintain healthy marriages and overall disadvantage.

This study investigates trends and patterns of non-marital childbearing in contemporary Russia, where the recent increase in non-marital childbearing could be the product of changing values and increasing independence or deepening poverty and disadvantage. Official statistics show that the proportion of overall births out of wedlock grew dramatically after the disintegration of the Soviet Union in 1991: from 14.6\% in 1990 to 29.8\% in 2004 (Zakharov, Vishnevskii, and Sakevich 2006). Yet no prior research has addressed the trends and correlates of the increase in this behavior. Using rich survey data with complete union and fertility histories, we address a series of questions: Is the surge in non-marital childbearing mainly due to increasing nonmarital fertility rates or to the decreasing fertility of married women? Have births to cohabiting women and single women followed similar trends? What roles do the 
intermediate steps in the process - conception and union formation after conception play in the rate of nonmarital childbearing? We answer these questions with respect to first births: because they are far more likely to occur out of wedlock than higher order births, and an analysis of first births provides the clearest picture of trends and correlates of non-marital childbearing.

Nonmarital childbearing has been increasing in many countries; what makes contemporary Russia an interesting case study? The answer lies in the sweeping changes which occurred during and after the break up of the Soviet Union. These changes could have led to either the North European "second demographic transition” or the U.S. "pattern of disadvantage," and thus the Russian case offers an ideal opportunity to disentangle the influence of ideational change and economic factors on non-marital childbearing patterns. First, the collapse of the "iron curtain” accelerated the spread of Western values and ideals associated with the second demographic transition, such as an emphasis on individual freedom, consumerism, and celebration of alternative lifestyles. Several demographers see these emergent norms as the principal driving force behind Russia’s increase in non-marital childbearing (Lesthaeghe and Surkyn 2002; Zakharov and Ivanova 1996; Zakharov 2008). Second, Russia’s transition to a market economy precipitated economic turmoil, poverty, and rising stratification (Gerber and Hout 1998; Gerber 2002). If non-marital childbearing is more common among the poor and marginalized in Russia (as in the U.S.), then we can conclude that the downward economic spiral has played a more important role than ideational change. Indeed, studies have shown that single-parent families in Russia disproportionately suffered during the transition to a new economy (Mroz and Popkin 1995; Klugman and Motivans 2001). By distinguishing births to single women from births to cohabiting women, estimating how the rates of each type 
of birth vary over time and across education levels, and conducting separate analyses of two key phases in the process that leads to different types of births (conception and legitimation), we show that Russia shares some aspects of the Northern European pattern cited by proponents of second demographic transition theory, but more features similar to those of the United States. Moreover, we find several aspects of non-marital fertility in contemporary Russia that neither of these general perspectives anticipates.

\section{THEORETICAL FRAMEWORK}

\section{Second Demographic Transition}

Demographers who have theorized about the second demographic transition (SDT) consider non-marital childbearing to be one of its signature elements (Lesthaeghe and Surkyn 2002; Van de Kaa 2001). In its most basic conceptualization, the SDT refers to a package of interconnected behaviors including cohabitation, declines or delays in marriage, postponement of childbearing, and below-replacement levels of fertility (McLanahan 2004; Sobotka et al 2003; Lesthaeghe and Neidert 2006). Dirk van de Kaa (2001) further specified that the behavioral changes of the second demographic transition occur in a sequence, starting with declines in the Total Fertility Rate and progressing through 15 stages that culminate in the decoupling of marriage and fertility. Over time, cohabitating unions become more stable, and the fertility behaviors of cohabiting and married couples converge, with fewer pregnancies to cohabiting couples prompting marriage (Raley 2001). With respect to fertility behavior, cohabitation becomes an "alternative to marriage” (Manning 1993). These arguments imply that childbearing becomes more common within cohabiting unions 
not sanctioned by formal state or religious institutions, but they do not imply that single motherhood increases.

Other conceptions of the SDT see changes in family formation behavior as the manifestation of new lifestyle choices related to ideational and cultural change such as an increased emphasis on individual autonomy, rejection of authority, and the rise of values connected to the "higher order needs" of self-actualization (Sobotka et al 2003; Lesthaeghe and Surkyn 2002, 2006; Lesthaeghe and Neidert 2006). Lesthaeghe and associates (2002, 2006) and van de Kaa (2001) draw connections to Ronald Inglehart's (1990) theory of post-materialism, which posits that values change as material needs are met, not only through economic development, but also through investments in education. Indeed, higher education is strongly correlated to the values associated with post-materialism and the SDT; research based on Inglehart's World Values Survey shows that individuals with higher education are more committed to individualism and gender equality and less supportive of authority (Weakliem 2002). Thus, although the SDT is not explicitly a model of how education leads to changes in family behavior, education can be used as a proxy for ideational change, with the most highly educated women being the first to adopt the new behaviors associated with the Second Demographic Transition (Lesthaeghe and Surkyn 2002).

Some researchers have argued that Russia, which maintained traditional family formation patterns for most of the Soviet era, embarked on its own version of the SDT in the late 1980s or early 1990s (Lesthaeghe and Surkyn 2002; Vishnevskii 1996; Zakharov 2008). They cite the increase in non-marital childbearing as key evidence of this development, even asserting that, “childbearing out-of-wedlock is becoming a universal social norm” (Zakharov 2008). They claim that with the fall of the "iron curtain” and the collapse of the Soviet economic system Russians have 
become more “westernized” through ideational change, as young people have been more exposed to the values and beliefs of capitalist, consumer-oriented countries. These arguments imply that in Russia education should be associated with nonmarital childbearing, since education is one of the main mechanisms leading to the changes in values and beliefs. Women with higher education should be the forerunners of the second demographic transition, and thus more likely to have children within cohabiting unions.

The account of non-marital childbearing in Russia derived from SDT theory implies two broad propositions that we can test with our data.

SDT Proposition 1: The increase in non-marital childbearing stems primarily from an increase in the rate of births to women in non-marital cohabitation. This follows from Raley’s (2001) interpretation of the SDT: fertility behavior within cohabiting unions becomes more similar to that of married couples. The SDT predicts that single women will increasingly cohabit (rather than marry) in response to a pregnancy, and cohabiting women will be less likely to marry. Thus, cohabitation will become an "alternative to marriage,” in that pregnancy no longer prompts marriage (Manning 1993).

SDT Proposition 2: Education is positively associated with higher rates of non-marital childbearing - particularly childbearing within cohabitation, but also single motherhood. As noted above, SDT theory postulates that the new norms and values behind the SDT are first embraced by the most educated members of society. Clearly, we would therefore expect a strong, positive educational gradient in the rate of births within cohabitation.

\section{Pattern of Disadvantage}


In stark contrast to SDT proposition 2, studies of the U.S. consistently show a negative association between non-marital childbearing and education, regardless of whether the births occur to single mothers or cohabiting couples (Rindfuss, Morgan, and Offutt 1996; Upchurch et al 2002; Ventura et al 1995). Low education is a wellestablished cause and consequence of material disadvantage, and single and cohabiting unmarried mothers in the U.S. have higher rates of poverty and welfare dependency (Lichter et al. 2003). As Edin and Kefalas (2005) show in their extensive qualitative study, two related mechanisms produce this association between disadvantage and non-marital childbearing: poor women often choose to have a child as a way to find meaning in their otherwise bleak lives and, at the same time, they see their romantic partners as economically or socially unsuitable for marriage (see also Anderson 1990). Thus, non-marital childbearing in the U.S. follows a very different pattern from that proposed by the SDT.

Nonetheless, although non-marital childbearing in the U.S. is often associated with single motherhood, 40\% of non-marital births in 1995 occurred within cohabiting unions, and the increase in the proportion of non-marital births during the 1990s stemmed largely from births to cohabiting couples (Bumpass and Lu 2000). Yet, before portraying childbearing within cohabitation as a harbinger of the SDT in the U.S., we should note that most evidence indicates that cohabitation is not becoming an alternative to marriage in that country (Raley 2001). Cohabiting unions in the U.S. are less stable than marriages (Brines and Joyner 1999; Bumpass and Lu 2000) and are about twice as likely to dissolve as marital unions following a first birth (Wu, Bumpass, and Musick 2001). Cohabitors are more likely to be unhappy or dissatisfied with their current situation (Brown and Booth 1996; Brown 2003) and suffer higher rates of physical violence and emotional abuse (DeMaris 2000; Kenney 
and McLanahan 2006). These findings suggest that cohabitation in the U.S. tends to be an arrangement of economic necessity or unstable relationships, not, as Lesthaeghe and Neidert (2006) suggest, a normative choice reflecting the spread of "higher-order" values associated with the SDT.

Russia could well resemble the United States in terms of non-marital childbearing being practiced by the least educated and most socially disadvantaged. Russia’s economic turmoil of the 1990s led to increases in unemployment, poverty, stratification, and general economic instability (Gerber and Hout 1998; Gerber 2002). Correspondingly, Russian women at the bottom of the social hierarchy may be especially likely to turn to childbearing as a way to find meaning in their lives, even as the pool of marriageable men available to them has dwindled. As in the United States, male unemployment or the lack of financial resources may be acting as a barrier to marriage or a wedding ceremony (Edin and Kefalas 2005), especially as cohabitation becomes more acceptable. In addition, an increase in anomie, or breakdown in social norms could be leading to an increase in risky behavior such as unprotected sex or other negative outcomes such as lower marital quality, alcoholism, or spouse abuse (Perelli-Harris 2006). Russian women are often reluctant to abort a first pregnancy due to fears of infertility and other medical concerns (Perelli-Harris 2005), so in a context of fewer men with the economic and emotional resources to marry, a constant rate of unintended pre-marital pregnancies would lead to an increase in non-marital births.

POD Proposition 1: The increase in non-marital childbearing stems primarily from an increase in the rate of births to single women. If economic deprivation and anomie are the driving forces behind non-marital childbearing in Russia, the growth of births to single women should outstrip the growth of births to cohabiting women. 
Childbearing within cohabiting unions could also reflect disadvantage if such unions are less stable than marriage as in the U.S. (Bumpass and Lu 2000), and other research in Russia does show that cohabiting unions are less stable than marriage (Muszynska 2008). Thus, the POD perspective does not rule out increasing births within cohabitation. But the mechanisms that link disadvantage to non-marital childbearing clearly imply that births to single women will grow more rapidly.

POD Proposition 2: Education is negatively associated with higher rates of non-marital childbearing - particularly single motherhood, but also births to cohabiting women. Education is a reliable and consistent proxy for disadvantage, and therefore women with the lowest levels of education should be most likely to have single births if disadvantage is the key factor.

\section{ANALYTIC STRATEGY}

\section{Estimating the rates of single, cohabiting, and marital births}

Our theoretical discussion emphasizes the distinction between two types of nonmarital first births: to single women and to cohabiting women. For simplicity, we refer to these as "single" and "cohabiting” first births, respectively, and we refer to first births to married women as "marital” births. In the first step of our analysis, we estimate the monthly rates of each of these three types of first births, defined simply as the number of first births of each type that occur during a given month divided by the number of women at risk of any first birth at the start of that month. ${ }^{1}$ Thus, the rate of single first births in a particular month is the number of single first births during that month divided by the number of childless women of childbearing age at the start of the month. Note that the risk set for single first births is the entire

\footnotetext{
${ }^{1}$ The choice of time unit for the rates of interest is arbitrary. We use "month" as the time unit because this is convention in fertility analyses and our data provide us with the exact months of each birth reported by respondents.
} 
population of childless women, not just single childless women. This may strike some readers as problematic on the grounds that only women who are single at the start of the month are truly "at risk" of having a single birth that month. Strictly speaking, this is incorrect: a woman who is pregnant at married at the start of the month could conceivably get divorced the day before she delivers and thus have a single birth. But we do recognize the point behind this objection, which is that the raw rates we estimate are produced by several discrete processes (union formation prior to conception, conception within union status, and changes in union status following conception) that, in turn, may exhibit different trends and associations with education. The second part of our analysis examines these processes separately.

In the first step of our analysis, we collapse these discrete processes into raw rates of single, cohabiting, and marital births because we believe these raw rates provide a more informative description than the conventional measure (the proportions of births that occur to single, cohabiting, and married mothers) for two reasons. First, all three birth rates vary independently, while only two of the three proportions do. Second, the rates directly measure different types of fertility behavior, while the proportions only indicate the relationships of each rate to the other two rates. In fact, the proportions can easily be derived from estimates of the rates. ${ }^{2}$ But the opposite is not the case: for example, increasing proportions over time of single births do not necessarily imply that the single births are occurring more frequently. They could even be occurring at decreasing rates, so long as the rate of marital births is decreasing more rapidly. The same goes for variation in proportions versus rates by levels of education.

\footnotetext{
${ }^{2}$ For example, the proportion of single births in a given month is simply the rate of single births divided by the sum of the three respective birth rates in that month
} 
The three birth rates of interest are equivalent to three competing risks, which we estimate in a discrete-time framework using multinomial logistic regressions (MLR) on a spell file consisting of all person-months when childbearing-age respondents were at risk for having a first birth. The basic form of the model is:

$$
h(m)_{i t}=p\left(y_{i t}=m\right)=\frac{\exp \left(\sum x_{i j t} \beta_{j m}\right)}{\sum_{m=1}^{M} \exp \left(\sum x_{i j t} \beta_{j m}\right)},
$$

where $\mathrm{h}(\mathrm{m})_{\text {it }}$ denotes the hazard that respondent $i$ will experience event $m$ in month $t$, which is equivalent to the probability that $i$ has the value $m$ on a nominal variable $y$ at the end of month $t$. There are four categories of $\mathrm{y}$ : a single birth, cohabiting birth, marital birth, and no birth in month $t$. The $\mathrm{x}_{i j t}$ represent respondent $i$ 's values on a set of $j$ potentially time-varying covariates at time $t$. The $\beta_{\mathrm{jm}}$ are parameters estimated from the data using maximum likelihood. The m subscript on $\beta_{\mathrm{jm}}$ shows that a separate parameter vector is estimated for each possible type of event. The model is identified by constraining all the elements in one such vector to equal zero (e.g. $\beta_{\mathrm{j} 1}=$ 0). The choice of such a "baseline" category of $m$ is arbitrary. The lack of a $t$ subscript on $\beta_{\mathrm{jm}}$ indicates that the coefficients do not vary over time, but we test for change over time in the effects of covariates by incorporating the appropriate interaction terms as $\mathrm{x}_{\mathrm{j}}$.

We estimate two versions of the model. The first includes only age and period as covariates. Based on the results of this model we calculate and plot the ageadjusted period-specific hazard rates for each type of non-marital birth. The second version of the model introduces dummy variables measuring respondent's education in the particular month at risk. Based on the results, we calculate and plot separate age-adjusted, period-specific hazards of each type of non-marital birth for women 
with different levels of education. These results provide informative descriptions of how non-marital childbearing rates vary by education and change over time. Even though they are based on a regression model, they are purely descriptive, in the sense that we use the model to estimate the unobserved age-adjusted rates during different periods of time and for women at different levels of education.

\section{Conception rates within union status and union status at birth, conditional on conception status}

As we alluded to earlier, rates of non-marital first births result from a complex process that can be decomposed into three discrete components: 1) the distribution of childless women of childbearing age across union statuses prior to conceptions; 2) the rates of conception within each union status; 3) the probabilities of being in each union at the time of birth, conditional on union status at time of conception. ${ }^{3}$ These discrete components may exhibit distinct trends and be related to education in distinct ways. For example, an increase in the proportion of childbearing-age women who are in cohabiting relationships or who are single (either because they have never married or because they have divorced) would increase the rate of non-marital births even without any change in the fertility behaviors typical of each union status: Russia's retreat from marriage and increasing cohabitation, which are analyzed elsewhere (Zakharov 1999; Hoem et al. 2008; Gerber and Berman 2008b), could be the main factor behind the increasing proportions of non-marital births.

\footnotetext{
${ }^{3}$ There are other ways to decompose non-marital fertility rates (e.g. Raley 2001, Upchurch et al 2002). For example, Smith, Morgan, and Koropeckyj-Cox (1996) show that the non-marital fertility ratio is an exact function of the age distribution of childbearing-age women, the proportion of women at each age who are not married, and the age-specific birth rates of married and unmarried women. Our sample is far too small to support the estimation of age-specific rates, so we cannot incorporate age distribution as a dimension of decomposition. We do, however, include standard controls for the effects of age on fertility. Our approach further decomposes the birth rates of married and unmarried women into rates of conception within each of three (rather than two) union statuses and probabilities of union status at time of birth conditional on conception status.
} 
Alternatively, fertility behavior within union status can change. Russian observers have documented a "sexual revolution” that started in the 1980s and developed with full force in the early 1990s (see Kon 1995). These changes in sexual behavior could easily have increased the rate of unintended pregnancies among single and cohabiting women, though they would not have that effect if, for example, the increased sexual activity was accompanied by an increased use in contraception. Sexual behavior and contraception usage could well vary by education in Russia: Gerber and Berman (2008a) found that university-educated women are more likely to use condoms.

Finally, greater normative acceptance of non-marital childbearing could lessen the social pressure to legitimize non-marital conceptions prior to birth. In fact, shotgun marriages were unusually common in Soviet Russia (Cartwright 2000; Zakharov 2006). According to the Russian GGS, in the early 1980s 46\% of pregnancies that started out-of-wedlock (and resulted in a live birth) ended with a marital birth. This percent declined subsequently, but was still at 37\% in 2000-03. This is relatively high compared to the United States: for example, $45 \%$ of premarital conceptions were legitimated in the 1970s (Manning 1993), but by the 1990s only 19\% were legitimated (Upchurch, Lillard, and Panis 2002). Therefore, decreased normative insistence on marriage as a prerequisite to childbearing could well have a profound effect on the probabilities of union status at birth following a single or cohabiting conception.

In order to fully understand the trends and correlates of non-marital births, we begin with a conceptual multi-state model that identifies the sequential states and the transitions between them that yield first births to married, cohabiting, and single women. We represent these steps as a series of transitions among nine states, whose 
hazards we denote $h_{j k}$, where $j$ denotes the origin state and $k$ the destination state

(Figure 1). States 1-3 represent the three union statuses prior to first conception. Women can change their union status prior to conceiving their first child and the rates at which they do so are $h_{12}, h_{13}, h_{21}, h_{23}, h_{31}$, and $h_{32}$. States 4-6 represent union status at the time of conception. The hazard rates $h_{14}, h_{25}$, and $h_{36}$ denote, respectively, the rates of conception among single, cohabitating, and married women. Only nonpregnant, childless women currently in a particular union status are at risk of conceiving within that union status. States 7-9 correspond to union status at the time of birth. No matter what a woman's conception status, she has some non-zero probability of giving birth within each union status, because her union status can change while she is pregnant. Note that the paths $h_{49}$ and $h_{59}$ represent the respective probabilities that single and cohabiting conceptions are "legitimized" by the time of birth. In contrast, $h_{67}$ and $h_{68}$ show that even women who conceive within marriage have some (small, but non-zero) risk of having a single birth (if during their pregnancy they divorce or their spouse dies), or a cohabiting birth (if their marriage ends and they enter cohabitation prior to delivery).

(Figure 1 about here)

Our conceptual model contains two noteworthy simplifications. First, in recognition of data limitations, we assume that all first conceptions lead to live births. In principle we could incorporate abortion and miscarriage by adding reverse arrows to the second series of paths and the corresponding reverse transitions $\left(\mathrm{h}_{41}, \mathrm{~h}_{52}\right.$, and $\left.\mathrm{h}_{63}\right)$. Here we cannot do so, because our data do not contain information on pregnancies that ended in miscarriage or abortion. Second, rather than analyze all transitions among union statuses during pregnancy, which can take many different 
permutations, ${ }^{4}$ we conceptualize the final step as a single transition from a particular conception status to a particular union status (including the same status as the original conception status) at the time of birth. Since the precise timing of this transition (e.g. two months versus four months into pregnancy) is of minor consequence, this model reduces to a straightforward multinomial logit model for the odds of each union status at time of birth, conditional on conception status.

As the multi-state model in Figure 1 illustrates, the rate of non-marital first births at a particular point in time is a function of the movement of the population between union statuses prior to conception, the rates of conception conditional on union status, and the probabilities of each union status at the time of birth conditional on union status at the time of conception. Ideally, we might attempt to model the entire set of transitions in Figure 1 jointly using simultaneous hazard equations with correlated residuals across equations, as researchers have previously done for subsets of them (Brien et al. 1999; Upchurch et al. 2002; Steele et al. 2005; Musick 2007). But modeling all the processes simultaneously poses computational challenges and places strong demands on the data, particularly because some of the transitions occur at very low rates. Moreover, we can achieve our primary goal of providing an empirically based account of change over time in non-marital childbearing patterns of Russian women with different levels of education in order to see whether Russia fits the SDT or the POD model by separately estimating models for a limited set of the transitions in Figure 1.

\footnotetext{
${ }^{4}$ Consider, for example, that a woman who is single at the time of conception can take multiple paths to the marriage at the time of birth: single to married, single to cohabiting to married, single to cohabiting to single to married, etc. While some of these paths may hold theoretical interest, for understanding the phenomenon of non-marital fertility the sequences themselves are substantially less important than union status at time of birth, so we subsume them all into a summary probability associated with each union status at the time of birth. It is easy to see that these probabilities vary by conception status: women who are single at conception most certainly have a higher probability of being single at the time of birth than do women who are already married when they conceive.
} 
We do not analyze changes in union status prior to first conception $\left(\mathrm{h}_{12}, \mathrm{~h}_{13}\right.$, $h_{21}, h_{23}, h_{31}$, and $h_{32}$ ) because others have examined trends in union formation behavior and its correlates in Russia (Zakharov 1999; Gerber and Berman 2008b; Hoem et al. 2008, Kostova 2007). These studies have demonstrated a steady increase cohabitation entry rates beginning in the early 1980s, as well as a decline in marriage entry rates, trends consistent with SDT proposition 1. However, they also report a significant positive effect of education on marriage entry rates, which contradicts SDT proposition 2 and confirms POD proposition 1. Here we treat union status as exogenously given and focus on the two steps pertaining to fertility behavior.

First, we estimate straightforward discrete-time event history models of first conception rates within each union status $\left(h_{14}, h_{25}, h_{36}\right)$ on the samples of personmonths where childbearing-age respondents who have not yet had a child are in a particular union status. Respondents at risk of first conception enter and exit the risk sets for conception within each union status whenever they change their union status. Although our hypotheses focus on conception rates of women who are single and cohabiting, we also estimate models of conception among married women for the sake of comparison and completeness.

Next, we analyze the probability of each union status at the time of birth following conceptions to single and cohabiting women. Because the precise timing and sequence of any changes in union status during pregnancy are less important than the status at time of birth, we estimate simple MLR models for union status at the time of birth of women who were, respectively, single $\left(\mathrm{h}_{47}, \mathrm{~h}_{48}, \mathrm{~h}_{49}\right)$ and cohabiting $\left(h_{57}, h_{58}, h_{59}\right)$ at the time of conception. (We also estimated models for women who were married at birth, but found that very few married women separated or entered cohabitation and do not present these results). The main covariates of interest in these 
models are, again, education and period. But we also include controls for age, school enrollment, and (where appropriate) duration of partnership.

\section{DATA AND MEASURES}

\section{Data}

Because official statistics do not include information on cohabiting unions at the time of birth, we analyze the Russian Gender and Generations Survey (GGS) ${ }^{5}$. The GGS conducted interviews with 7038 women aged 15-79. The overall response rate was $48 \%$, but comparisons show that the GGS is generally comparable with the Russian census in terms of major population characteristics (Houle and Shkolnikov 2005). ${ }^{6}$ The GGS has a very low response-rate (15\%) in the largest urban areas of Russia Moscow and St. Petersburg - where births within cohabitation could be increasing most quickly among the highly educated. Thus, the survey may not be representative of these major urban areas, where childbearing within cohabitation may be increasing the most quickly. Finally, the GGS did not obtain residential mobility histories, so it cannot be used to model differences in non-marital fertility by locality type. Limitations aside, the GGS is suitable for analyzing fertility and union behavior in Russia, because it includes complete retrospective marital and fertility histories, distinguishes between married and unmarried partnerships, and offers ample statistical power for testing hypotheses about trends over time and the associations between fertility and education.

In order to analyze the rates of first births and first conceptions by union status we created a spell file where the observations consist of person-months when

\footnotetext{
${ }^{5}$ For more information on the GGS see http://www.unece.org/pau/ggp/Welcome.html.

${ }^{6}$ The main disparities are that the GGS under-sampled women aged 30-39 and over-sampled women aged 40-54 at the time of the survey. It also slightly over-estimated women in partnership, perhaps because they were more likely to be at home.
} 
respondents were of childbearing age (15-49) and had not yet had a first birth. Conceptions are defined by backdating live births 8 months, when the decision to keep a pregnancy is often made. Unfortunately, we have no information on conceptions that ended in abortions or miscarriages, nor can we identify conceptions that took place within 9 months of the time of the survey. Accordingly, we censor all respondents at the end of 2003. Our results referring to conception pertain only to conceptions that eventually result in a birth and do not take into account changes that may result from declining abortion rates.

\section{Measures}

Educational attainment and enrollment. Time-varying measures for educational level and enrollment were created using two questions: highest level of education achieved and date of graduation or whether respondent was enrolled in school at the time of the interview. We assumed that school enrollment was continuous until date of graduation, and all models that include education contain a time-varying dummy variable for current school enrollment. We assumed that level of educational attainment changed at average ages of graduation associated with each particular degree, which we computed from observed responses in the GGS. ${ }^{7}$ We then created time varying dummy variables for highest education achieved by a particular month. We started with five education categories, but we found in all analyses that we could collapse them into the following three without sacrificing the fit of our models: postsecondary (semi-professional or “specialized” secondary degree, some university,

\footnotetext{
${ }^{7}$ For example, women whose highest level of education was a college degree were coded with less than secondary education from age 15-18, secondary education until month of college graduation, and college education beyond that date. We imputed educational enrollment for women with missing graduation dates based on average graduation dates from the entire sample.
} 
university degree, and graduate degree), secondary (including general secondary diplomas and lower vocational or "PTU” training), and less than secondary. ${ }^{8}$

Period. After experimenting with several specifications of calendar year (including linear time and 5-year periods), we found that 4-year intervals starting in 1980 and ending in 2003 fit best. These periods correspond with social and economic changes: 1980-83 corresponds to pre-Gorbachev era (full blown Soviet system); 1984-88 marks the start of Gorbachev’s rule and his initial efforts to reform the system; 1988-91 saw full-fledged perestroika and the institution of family benefits; 1992-1995 witnessed the collapse of the Soviet Union, introduction of radical market reforms, and the onset of economic crisis; the crisis continued despite relative political stability from 19961999; and 2000-03 was a period of strong economic recovery. We use 1996-99 as the reference category, because fertility and marriage rates were lowest during this period.

Age and union duration. Age refers to current age in a particular month at risk. Union duration refers to the number of months since the respondent married or began cohabiting with their current partner. These variables may be correlated with period and education and they may affect the outcomes we model; thus, they must be controlled statistically. We ran each model with several specifications of both variables (e.g. second and third-order polynomials), and we adopt the specification that provides the best model fit based on likelihood ratio tests. We also tested for change over time in the first-order effects, as described in more detail when we discuss the results.

\section{RESULTS}

\footnotetext{
${ }^{8}$ We used straightforward likelihood-ratio tests to ascertain whether the three-category specification of education yields and inferior fit compared to the five-category specification. We spare the reader the details of these tests, but we will supply them upon request.
} 


\section{First birth rates by union status}

According to the GSS data, the percentage of first births that occurred out of wedlock increased steadily from $17 \%$ in $1980-83$ to $33 \%$ in $2000-2003$ (Figure 2). Until 20002003, births within cohabitation account for most of the increase in the percentage of non-marital births, with the percentages of births to single women fluctuating around $11 \%$. In the last period, however, births to single women rose to $16 \%$, while births to cohabiting women remained at $17 \%$.

(Figure 2 about here)

Although Figure 2 is the conventional way to depict trends in non-marital fertility, it can be misleading. First, both union status and fertility vary substantially with age, so a proper measure of trends should control for age. Second, different trends in union status-specific fertility can produce the same set of changing percentages over time. For example, the increasing percentage of first births to cohabiting women could reflect either an increase in the rate at which cohabiting births occur to childless women or a decrease in the rate at which married births occur. Or both rates could be decreasing, with the rate of marital fertility decreasing more rapidly. To speak of a surge or epidemic of non-marital childbearing implies that the rates of single and/or cohabiting births actually increase, and whether they do cannot be determined from Figure 2. To obtain age-adjusted estimates of the periodspecific rates of each type of first birth we estimated the discrete-time competing risk model described above, with only age and period as covariates. Using the coefficients estimated from the data, we then calculate expected rates of single, cohabiting, and marital births during each period, which are plotted in Figure $3 .^{9}$

\footnotetext{
${ }^{9}$ The best fitting specification of the effect of age in this model was a second-order polynomial. To calculate expected rates we must select values for all covariates in the model. For figure 3, we set age at 22 years old. Changing the value of age has only trivial impact on the patterns of change over time
} 
(Figure 3 about here)

Figure 3 is far more informative than Figure 2. It shows that the increasing proportions of non-marital first births in Russia since the 1980s has been driven almost entirely by a sharp decline in the rate of marital births, coupled with relative stability in the rates of cohabiting and single births. It is not the case that childless women of childbearing age increased their rates of non-marital births; instead, they have been having marital births at lower rates. The rate of marital births increased in the late 1980s, but then it fell sharply during the 1990s before stabilizing in the early 2000s, perhaps reflecting the resurgent Russian economy. This trend is consistent with other studies of overall fertility in Russia (Zakharov 2008). The rates of births to single and cohabiting mothers, however, exhibit very moderate fluctuations. Although there appears to be a slight secular trend of increase in cohabiting births, it pales in magnitude compared to the sharp decline in marital fertility. Thus, the majority of the percentage increase in non-marital childbearing has been the result of declining marital fertility - not increases in childbearing within cohabitation or to single mothers. Of course, as depicted in Figure 1, these patterns could reflect changes over time in any of the processes that combine to produce the three different fertility rates: the distribution of union status among childless, childbearing-age women, conception rates within each union status, conception-status specific probabilities of each union status at the time of birth, (e.g. legitimation or entry into cohabitation), or some combination of these. In fact, our subsequent analyses show that neither changes in conception rates within union status nor probabilities of each union status conditional on conception status account for the patterns in Figure 3: the 
changing distribution of union statuses among childless women of childbearing age plays a decisive role.

\section{The association between first birth rates by union status and education}

As described above, SDT theory predicts that women with higher education should be the forerunners in childbearing within cohabitation, while the POD perspective predicts that women with lower education are more likely to bear children out-ofwedlock. The descriptive statistics presented in table 1 show that in general, childbearing to single and cohabiting women follows the pattern of disadvantage. In every period women with less than secondary education had the highest percentage of non-marital births. There are no consistent differences between women with secondary and post-secondary education.

(Table 1 about here)

The descriptive statistics, however, do not indicate whether differences between educational levels are statistically significant or changed over time. To address these issues, we incorporated measures of education into our competing risk model. For this model and the other models described below, we started with the full 5-category specification of education, plus a measure of current school enrollment. We then collapsed as many education categories as we could without sacrificing model fit in order to eliminate non-significant differences in education categories. As a result of this specification search, our results include only statistically significant differences in education categories. Next, we test for change over time in the effects of education on the logged hazards, again using likelihood ratio tests to assess whether model fit improves significantly with the addition of the interactions. We test two forms of interaction: linear change across period (using an integer-scored scalar 
term for period in the interaction) and "post-Soviet” change (using a single dummy variable for post-1991).

The optimal specification for the competing risk model is the three-category specification we described above: post-secondary (semi-professional or "specialized" secondary degree, some university, university degree, and graduate degree), secondary (including general secondary diplomas and lower vocational or "PTU" training), and less than secondary (see Appendix Table A). No interactions are statistically significant - in fact, this holds for all models we estimate. The association between education and the raw rates of single, cohabiting, and marital births can be seen by plotting the predicted rates for the highest and lowest education levels that the estimates from our preferred model imply (Figure 4). ${ }^{10}$ The evidence is more consistent with the POD perspective than with SDT: the rate of marital childbearing is significantly higher for women with post-secondary education than for women with less than secondary, while the least educated women have the highest rates of both single and cohabiting births. Figure 4 also shows that the education gap in non-marital childbearing stems mainly from the lower rates of marital births among those with less than secondary. Although they have consistently higher rates of cohabiting and single births than more educated women do, the reverse gap in marital births is much greater in magnitude. Another result that casts doubt on the SDT perspective is that the rates of cohabiting and single births to more educated women are about the same, while SDT predicts that cohabiting births should be more

\footnotetext{
${ }^{10}$ Note that the variation by education in the rates changes somewhat over time despite the lack of interaction terms between education and period in the model. This reflects the non-linear functional form of the MLR model: the annual changes in the baseline due to period effects inevitably produce modest changes in the "effects" of education on the raw hazards. But concerns that the apparent changes in education are artifacts of our specification should be allayed by the fact that we tested for and ruled out interactions between education and period. Thus, the pattern in Figure 4 provides the best fit to the data.
} 
common. In contrast, the least educated women generally have somewhat higher rates of single than cohabiting births, which is predicted by POD. ${ }^{11}$

(Figure 4 about here)

\section{Conception rates by union status}

We now turn to our explicit models of fertility behavior by different union types, models which demonstrate whether the trends in rates and their associations with education reflect the changing distributions across union statuses, fertility behavior, or both. We first estimate discrete time models of the hazard of conception within each union status $\left(\mathrm{h}_{14}, \mathrm{~h}_{25}\right.$, and $\left.\mathrm{h}_{36}\right)$. The resulting models cannot be compared directly, because they include different risk sets and processes, but they provide a general idea of how the timing of fertility differs by education once (or whether) women have entered a union. Because our main focus in this section is variation by education; we control for age, period, school enrollment, and duration in union (for the married and cohabiting women), which may be correlated with education and period and are likely to affect conception rates. We found that different specifications of these control variables and of education were optimal for each of the three risk sets (Table 2). Here, too, we did not find any significant interactions between education and period. We also tested for change across periods in the effects of age and/or duration of relationship (for married and cohabiting respondents). We found no significant interactions for either single or cohabiting conceptions. For marital conceptions, we did find a significant interaction involving duration, as shown in Table 2.

(Table 2 about here)

Table 2 presents the preferred model specifications for each type of union. The effects of education differ for each model. Once in a marital union, women with less

\footnotetext{
${ }^{11}$ When interpreting these results in Figure 4, bear in mind that the model controls for school enrollment and that the measurement of education, while crude, is time-varying.
} 
than secondary education had first conception rates that were $21 \%$ lower than women with secondary or vocational education, while women with post-secondary education had first conception rates that were $17 \%$ higher, although this term is not significant (it is, however, when the interaction term between duration and post-Soviet change is not included in the model). This result suggests that women with post-secondary education may have already been postponing marriage and thus may have quickly become pregnant after marriage. The opposite is true for the single women analyses; single women with semi-professional or university education had conception rates that were $36 \%$ lower than single women with lower levels of education. Relative to women with a secondary education, it is rare for women with higher education to conceive out of union. Finally, education did not have any significant effects at all on conception rates for cohabiting women. This result does not explicitly support either the SDT or the POD perspective.

To illustrate how first conception rates have changed over time, we plot the predicted rates implied by our preferred models in Figure 5. Figure 5 shows not only the rate at which conceptions decline with union duration, but also how the overall conception rates contracted from 1980-83 to 2000-03. Regardless of union type or period, the rate of conception is always highest closer to the time of union formation, but the steepness of the curve for both marital and cohabiting births changes over time. Interestingly, in the early 1980s, there was little difference by union type in conception rates at 3 months- probably because modern contraception was largely unavailable and once co-residence began, women quickly became pregnant. Contrary to our expectations, conception rates in cohabitation in 1980 were higher than in marriage. By 2000-03, this pattern had reversed and cohabiting women had lower conception rates. The significance of the interaction term between duration and the 
post-Soviet period indicates that after 1991, the decline in conception rates was less steep - women had started to delay conceptions within marriage. This delay could have been because contraception effectiveness and availability improved or couples wanted to enjoy more time within marriage child-free. We leave this to other studies to further investigate this trend.

(Figure 5 about here)

These findings have interesting implications for our arguments. SDT theory predicts that the postponement of childbearing occurs concomitantly with the increase in cohabitation, and it may even follow that women in cohabiting unions postpone childbearing more than women in marital unions. However, the monotonic decline in cohabiting conception rates over 30 months since the start of a union (Figure 5) shows that conception rates decline with lengthening duration. Further, the lack of significance of the interaction terms indicates this occurred without postponement. This result suggests that cohabitation is not becoming a preferred environment for conceiving a child. Instead, cohabitation in Russia could be becoming even more similar to a prelude to marriage or a stage in the marriage process (Heuveline and Timberlake 2004). At the same time, we see no evidence of the increasing conception rates among single mothers postulated by the POD perspective. Although we do not plot these rates (obviously impossible to do on a figure representing union duration), the coefficients on table 3 indicate that conception rates did not change significantly, with the exception of a slight increase in 1988-91. The predicted rates (approximately .006 in all periods) are substantially lower than the predicted rates of conceptions by both cohabiting and married women. In conclusion, this analysis of conception rates by union status does not clearly support either the SDT or POD perspective and points to the need for alternative explanations. 


\section{Changes in union status during pregnancy}

The substantial decline in the rate of conceptions to cohabiting women and its lack of variation by education mean that the stability (or modest increase) and educational differences in the overall rate of cohabiting births (Figures 3 and 4) must reflect dynamics in changes in union status. To see which, we turn now to our MLR models of union status at the time of birth for pregnancies initially conceived by single $\left(\mathrm{h}_{47}\right.$, $\mathrm{h}_{48}$, and $\left.\mathrm{h}_{49}\right)$ and cohabiting $\left(\mathrm{h}_{57}, \mathrm{~h}_{58}\right.$, and $\left.\mathrm{h}_{59}\right)$ women. ${ }^{12}$ In these models a single dummy variable denoting less than secondary education is the preferred specification, and once again we found no significant interactions between education and period.

By plotting the implied predicted probabilities of each union status at the time of birth for each period (holding age at 22 and education at secondary or more), we see that there is no clear trend towards declining legitimation (Figure 7, which is based on Appendix Table B). The probability of marriage prior to birth to single women fluctuated around 50\% until 2000-2003 and then declined sharply. Also, contrary to SDT we see no evidence of a trend toward increasing cohabitation by women who conceive while single. As for pregnancies to cohabiters, there is also no trend toward remaining within cohabitation: the highest predicted probability of doing so peaked in the mid-1980s and declined in 2000-2003. Consistent with POD, among women who conceive out of wedlock those with the least education are significantly less likely to get married and more likely to be single at time of birth, whether they were single or cohabiting initially (Figure 8). Contrary to SDT, education has scant influence on the probability of cohabiting at time of birth for women who experience either form of non-marital pregnancy.

\footnotetext{
${ }^{12}$ We do not analyze union status at time of birth for pregnancies conceived by married women, because too few marital unions dissolved during pregnancy to support such an analysis.
} 
(Figure 7 and Figure 8 about here)

Our results thus far indicate that the rate of conceptions to cohabiting women declined from 1980-2003 at about the same pace as the rate of conceptions to married women, and the rates of legitimizing cohabiting pregnancies and entering cohabitation after single pregnancies both exhibited moderate and relatively trendless fluctuation. What, then, can explain the pattern in Figure 2 and the much discussed "increase" in non-marital childbearing in Russia? First, we emphasize again that the "increase" in non-marital childbearing in fact reflects a sharp decline in the rate of marital childbearing coupled with relatively stable rates of cohabiting and single childbearing. But what can explain the stability of cohabiting childbearing, given the results just alluded to? The answer is simple: the increase in the proportion of childless women of childbearing age living in cohabiting relationships was sufficient to offset the declining conception rate within cohabitation (Figure 9).In 1982, only $4 \%$ of childless women aged 15-49 lived in cohabiting unions, but twenty years later $16 \%$ of childless women lived in cohabiting unions. Part of the upward trend observed in figure 3, however, is due to sampling error and changes in cohort size; even though the figure shows women aged 15 to 49, the proportion of women at older ages increases over time, and some of the decline in the percent of single women is due to the slightly older mean age. Nonetheless, it is striking how much cohabitation has taken off as a new family formation strategy. The steep decline in marriage and increase in cohabitation are similar to those found in other studies (Gerber and Berman 2008a, Hoem et al 2008, Kostova 2007). Without any changes of union status-specific rates of conception the trends in Figure 3 imply that percentages of single and cohabiting births would increase.

(Figure 9 about here) 


\section{DISCUSSION}

Since the 1990s, nonmarital childbearing in Russia has increased dramatically, at least by the conventional measure of the percentage of births that occur out of wedlock. Most researchers studying this issue have assumed that this apparent increase is due to the "Second Demographic Transition," brought on by the massive social change that occurred after the collapse of the Soviet Union (Zakharov 2008, Hoem et al. 2008, Lesthaeghe and Surkyn 2002). The usual assumption is that Russia is following the path of Western European countries, particularly Northern European countries, which started experiencing massive increases in the percentage of births to cohabitors in the 1970s. However, no studies on Russia (and few in Western Europe, for that matter) have investigated the trends in the rates of single, cohabiting, and marital births that underlie the trends in the percentage of births that occur out of wedlock or the associations between these rates and education. Nor have any studies specifically examined conception rates within each union status or the probabilities of each union status at time of birth conditional on conception status. Our study provides an indepth analysis into the trends and correlates of nonmarital childbearing and finds that the situation has more in common with the "pattern of disadvantage" characterizing non-marital fertility in the United States than with the SDT pattern. However, the Russian case also exhibits some important features that neither pattern anticipates.

To arrive at these conclusions, we have focused on two types of evidence. The first examines how the trends and composition of nonmarital childbearing changed over time. The SDT predicts that there should be an overall increase in birth rates within cohabitation, while the POD emphasizes an increase in childbearing to single mothers, although increases in childbearing within unstable cohabiting unions - 
increasingly the case in the U.S. - could also be consistent with the POD (Raley 2001). Neither prediction is borne out in the Russian case. The rate of cohabiting first births has remained stable, with only a slight increase from 1980-2003. The rates of single births also remained relatively stable over this period. The apparent "surge" in non-marital childbearing stems entirely from a sharp decline in the rates of first marital births throughout the 1990s. Neither SDT nor POD explicitly predicts a decline in marital births coupled with stability in single and cohabiting births. Thus, neither theory provides much help for understanding the trends and dynamics of nonmarital childbearing in Russia. The only finding consistent with the SDT is that the proportion of childless women of childbearing age in cohabiting relationships grew steadily in Russia since the early 1980s, but the reasons for the increase in cohabitation are beyond the scope of this paper and have been studied elsewhere (Hoem et al 2008, Kostova 2007, Gerber and Berman 2008b)

We then focus on steps in the process of nonmarital childbearing, specifically conception behavior within union status and changes in union status during pregnancy. The SDT predicts that fertility behavior within cohabiting unions should become more similar to that of married couples (Raley 2001), but we find that in Russia, conception rates within cohabitation have not increased over time, nor have they become similar to that of married people. The SDT also predicts that single women will increasingly cohabit (rather than marry) in response to a pregnancy, and cohabiting women will be less likely to marry (Raley 2001). Our results indicate that this has not happened in Russia; instead there has been very little change in union formation during pregnancy for either single or cohabiting women, with the exception of 2000-03, when single women became less likely to enter into cohabitation or marriage. Overall, the lack of change in legitimation behavior seems very similar to 
the situation in the U.S. in the early 1990s, when increases in the proportion of births to cohabitors were driven by the increase in the proportion of the population that was cohabiting (Raley 2001).

We also examine the relationship between nonmarital childbearing and education. We argue that although the SDT has been conceptualized in many different ways (see Sobotka 2008 for a discussion), the underlying ideas usually associated with the SDT, for example secularization, individualism, self-expression and self-actualization, are intrinsically linked to higher education. Thus, it follows that highly educated women should be the forerunners of Second Demographic Transition behaviors, namely childbearing within cohabitation. The Pattern of Disadvantage, on the other hand, strongly predicts an association between lower education and childbearing within cohabitation or to single mothers. In this paper, we find the strongest support for the POD in Russia; the least educated women have the highest birth rates within cohabitation, not to mention the highest birth rates as single mothers. Single women with the highest education have significantly lower first conception rates than women with other educational levels, even after controlling for school enrollment. After conception, the difference in educational level becomes most pronounced; the least educated women who conceived while cohabiting are far more likely to remain within cohabitation or experience union dissolution, while the least educated women who conceived while single are the least likely to enter any type of union. Thus, the majority of the education results show strong support for the POD. However, there is one important exception: we found no difference by level of education for conception rates within cohabitation, a result which can not be explained by the POD or SDT. Further research is needed to elucidate the characteristics of women who conceive within cohabitation. 
Some limitations of this study must be noted. First, response rates in Moscow and St. Petersburg - by far the largest urban areas in Russia - were very low, meaning that the survey can only be considered representative of the rest of Russia. It could very well be that the Second Demographic Transition is advancing much more quickly in these cities, and that highly educated women are indeed starting to bear children within cohabitation. We also do not have time-varying covariates for size of locality and can not capture urban-rural effects that may be independent of education. In general, our models are relatively parsimonious and may not be accounting for other factors which influence nonmarital childbearing, such as parental characteristics, housing availability, employment opportunities, and characteristics of the partner. Finally, due to our modeling decisions, we are unable to truly estimate the causal effects of education on nonmarital childbearing, especially given that the effects of education may differentially affect union transitions at multiple points along the path to a nonmarital birth. However, our goal is to adjudicate between two patterns of nonmarital childbearing (SDT and POD), goals which are met through descriptions of the association between education and birth by union status, as well as a focus on behaviors surrounding a nonmarital pregnancy.

To summarize, we find that the primary cause of the post-Soviet increase in the proportion of births out-of-wedlock is not due to changes in the fertility behavior of cohabitors, nor to changes in union behavior after conception, but due to the increasing proportion of women who cohabit before conception. More women are now exposed to the risk of conceiving within cohabitation, but once they conceive, they are as equally likely as before to marry. Thus, the increase in births within cohabitation is part and parcel of the "retreat" from marriage in Russia (Gerber and Berman 2008b, Hoem et al 2008). Nonetheless, the relationship between education 
and nonmarital childbearing has not changed over time; the least educated women have the highest birth rates within cohabitation and as single mothers, due to the lower probability of legitimating a nonmarital conception. Thus, the least educated women are at the greatest disadvantage when it comes to marriage after conception. We speculate that this is not because they are rejecting the institution of marriage in favor of autonomy, but rather because they or their partners are "unsuitable” for marriage, either due to lack of employment opportunities or other unfavorable characteristics (Edin and Kefalis 2005; Gibson-Davis et al 2005). The collapse of the Soviet Union, which led to increases in economic instability, poverty, and anomie would have increased the number of women who were at risk of being in this situation

In conclusion, this study suggests that patterns of disadvantage lead to a divergence in family formation strategies. Marriage remains an indicator of the greater opportunities and stability associated with higher education. This pattern seems to have been exacerbated by the economic turmoil during the transition to a labor market economy. Now, as inequality increases in Russia, family behaviors will most likely continue to diverge, as in the U.S. As MacLanahan (2004) argues (although her definition of the SDT is much broader than ours): “...the forces that are driving the transition are leading to two different trajectories for women...One trajectory - the one associated with delays in childbearing and increases in maternal employment - reflect gains in resources, while the other - the one associated with divorce and nonmarital childbearing -reflects losses. Moreover, the women with the most opportunities and resources are following the first trajectory, whereas the women with the fewest opportunities and resources are following the second.” These two trajectories appear to be emerging in Russia. 
Taken as a whole, these results suggest that demographers should attend closely to differences between single and cohabiting women in their analyses; single women exhibit different behaviors from cohabiting women and cohabiting women can not simply be included with married women. In addition, research on non-marital childbearing should incorporate more sophisticated techniques for studying the complicated process of nonmarital childbearing, a process which can involve changing union status at multiple points in the life-course; our study provides one innovative approach, but there is room for development. Finally, further research needs to analyze the trends and correlates of cohabiting unions and non-marital childbearing in Europe and other countries where the trend is increasing. Most studies that point to the diffusion of the second demographic transition rely on macro-level indicators for evidence, rather than conducting individual-level analyses to show that cohabitation and non-marital childbearing are associated with certain values or ideas. Few European studies analyze the relationship between non-marital childbearing and cohabitation and education, economic conditions, or values. Only studies which attend to these relationships can determine whether the second demographic transition is spreading or whether the family formation strategies of the highest and least educated are diverging. 


\section{REFERENCES:}

Anderson, Elijah. 1990. Streetwise: Race, Class, and Change in an Urban Community. Chicago: University of Chicago Press.

Brien, Michael J., Lee A. Lillard, and Linda J. Waite. 1999. "'Interrelated familybuilding behaviors: Cohabitation, marriage, and nonmarital conception" Demography 36:535-551.

Brines, Julie and Kara Joyner. 1999. “The Ties that Bind: Principles of cohesion in cohabitation and marriage.” American Sociological Review. 64: 333-355.

Brown, Susan L. 2003. "Relationship quality dynamics of cohabiting unions.” Journal of Family Issues 24: 583-601.

Brown, Susan and Alan Booth. 1996. “Cohabitation versus marriage: A comparison of relationship quality.” Journal of Marriage and Family 58: 668-678.

Bumpass, Larry and Hsien-Hen Lu. 2000. “Trends in cohabitation and implications for children’s family contexts in the United States.” Population Studies 54: 29-41.

Cartwright, Kimberly. 2000. "Shotgun Weddings and the Meaning of Marriage in Russia: An Event History Analysis.” History of the Family. 5: 1-23.

DeMaris, Alfred. 2001. "The influence of intimate violence on transitions out of cohabitation.” Journal of Marriage and Family 63: 235-246.

Edin, Kathryn and Maria Kefalas. 2005. Promises I Can Keep: Why poor women put motherhood before marriage. Berkeley: University of California Press.

Gerber, Theodore P. 2002. "Structural Change and Post-Socialist Stratification: Labor Market Transitions in Contemporary Russia. American Sociological Review. 67: 629-59. 
Gerber, Theodore P. and Danielle Berman. 2008a. “Heterogeneous Condom Use in Russia.” Studies in Family Planning. 39: 1-17.

Gerber, Theodore P. and Danielle Berman. 2008b. “Russia’s Retreat from Marriage: Economic Crisis, Second Demographic Transition, or Third Way?” Unpublished manuscript. Department of Sociology, University of Wisconsin.

Gerber, Theodore P. and Michael Hout. 1998. "More Shock Than Therapy: Employment and Income in Russia, 1991-1995.” American Journal of Sociology. 104: 1-50.

Gibson-Davis, Christina, Kathryn Edin, and Sara McLanahan. 2005. "High hopes but even higher expectations: The retreat from marriage among low-income couples.” Journal of Marriage and Family 67: 1301-1312.

Heuveline, Patrick and J.M. Timberlake. 2004. “The Role of Cohabitation in Family Formation: The United States in Comparative Perspective.” Journal of Marriage and Family 66(6):1214-30.

Hoem, Jan M., Aiva Jasilioniene, Dora Kostova, and Cornelia Muresan. 2008. “The Second Demographic Transition in Selected Countries in Central and Eastern Europe: Union Formation as a Demographic Manifestation.” MPIDR Working Paper 2007-026. Max Planck Institute for Demographic Research, Rostock, Germany.

Houle, Rene and Vladimir Shkolnikov. 2005. "Low response rates in the cities of Moscow and Sankt-Peterburg and GGS-Census comparisons of basic distributions." Max Planck Institute for Demographic Research.

Inglehart, Ronald. 1990. Culture Shift in Advanced Industrial Society. Princeton University Press.

Kenney, Catherine T. and Sara S. McLanahan. 2006. "Why are cohabiting 
relationships more violent than marriages?” Demography 43 127-140.

Kiernan, Kathleen. 2004. "Unmarried cohabitation and parenthood: here to stay?

European perspectives.” In D.P Moynihan, T. Smeeding and L.Rainwater (eds)

The Future of the Family. Russell Sage Foundation, p. 66-95.

Klugman, Jeni, and Albert Motivans, eds. 2001. Single Parents and Child Welfare in the New Russia. UNICEF: PALRAVE.

Kon, Igor S. 1995. The Sexual Revolution in Russia: From the Age of the Czars to Today. Translated by James Riordan. New York: The Free Press.

Kostova, Dora. 2007. "The emergence of cohabitation in a transitional socioeconomic context: evidence from Bulgaria and Russia." Demografia 50(5).

Lesthaeghe, Ron J., and Lisa Neidert. 2006. “The Second Demographic Transition in the United States: Exception or Textbook Example?” Population and Development Review. 32:4.

Lesthaeghe, R. and J. Surkyn. 2002. "New forms of household formation in Central and Eastern Europe: Are they related to newly emerging value orientations?" Brussels, Belgium: Interface Demography (SOCO) Vrije Universiteit Brussel. Lichter, Daniel, Deborah Roempke Graefe, and J. Brian Brown. 2003. “Is Marriage a Panacea? Union formation among economically disadvantaged unwed mothers," Social Problems 50: 60-86.

Manning, Wendy D. 1993. "Marriage and cohabitation following premarital conception." Journal of Marriage and the Family 55:839-850.

McLanahan, Sara. 2004. " Diverging Destinies: How Children Are Faring Under the Second Demographic Transition." Demography 41:607-627.

Mroz, Thomas and Barry V. Popkin. 1995. "Poverty and the Economic Transition in the Russian Federation.” Economic Development and Cultural Change 22:2-31. 
Musick, Kelly. 2007. "Cohabitation, nonmarital childbearing and the marriage process." Demographic Research 16(9):249-286.

Muszynska, Magdalena. 2008. "Women's employment and union dissolution in a changing socio-economic context in Russia." Demographic Research 18(6):181204.

Perelli-Harris, Brienna. 2005. "The path to lowest-low fertility in Ukraine,” Population Studies 59: 55-70.

2006. "The influence of informal work and subjective well-being on childbearing in post-Soviet Russia.” Population and Development Review. 32:4. 729-753.

Raley, R. Kelly. 2001."Increasing fertility in cohabiting unions: Evidence for the second demographic transition?” Demography 38: 59-66.

Rindfuss, Ronald R., S. Philip Morgan, and Kate Offutt. 1996. "Education and the changing age pattern of American fertility: 1963-1989." Demography 33(3):277290.

Smith, Herbert L., S. Phillip Morgan, and T Koropeckyj-Cox. 1996. “A decomposition of trends in the nonmarital fertility ratios of blacks and whites in the United States, 1960-1992.” Demography. 33:141-51.

Sobotka, Tomáš, Kryštof Zeman, and Vladimíra Kantorová. 2003. " Demographic shifts in the Czech Republic after 1989: A second demographic transition view ," European Journal of Population 19 (3): 249 - 277.

Steele, Fiona, Heather Joshi, Constantinos Kallis and Harvey Goldstein. 2006. "Changing compatibility of cohabitation and childbearing between young British women born in 1958 and 1970." Population Studies 60(2):137-152.

Surkyn, Johan and Ron Lesthaeghe. 2004. "Value orientations and the Second 
Demographic Transition (SDT) in Northern, Western, and Southern Europe: An update." Demographic Research Special Collection 3. 3:45-86.

Upchurch, Dawn M. Lee A. Lillard, Constantijn W. A. Panis. 2002. “Non-marital childbearing: Influences of education, marriage, and fertility.” Demography 39: 311-329.

van de Kaa, D. 2001. "Postmodern fertility preferences: From changing value orientation to new behavior." Global fertility transition. Supplement to Population and Development Review. 27:290-338.

Ventura, Stephanie, and Christine A. Bachrach. 2000. "Nonmarital childbearing in the United States, 1940-99." in National Vital Statistics Reports. Centers for Disease Control and Prevention.

Vishnevskii, Anatoly G. 1996. "Family, fertility, and demographic dynamics in Russia: analysis and forecast." in The conference on "Russia's Demographic 'Crisis'”, edited by Julie Da Vanzo. Santa Monica, CA: RAND Center for Russia and Eurasia.

Weaklim, David L. 2002. "The effects of education on political opinions: An international study." International Journal of Public Opinion Research 13(2):141157.

Wu, Lawrence J. and Barbara Wolfe. 2001. Out of Wedlock: Causes and Consequences of Non-marital Fertility. New York: Russell Sage Foundation.

Wu, Lawrence L., Larry L. Bumpass, and Kelly Musick. 2001. "Historical and Life Course Trajectories of Non-marital Childbearing," in Out of Wedlock: Causes and Consequences of Non-marital Fertility. edited by Lawrence J. Wu and Barbara Wolfe. New York: Russell Sage Foundation.

Zakharov, Sergei V. and Elena Ivanova. 1996. "Fertility decline and recent changes in 
Russia: on the threshold of the Second Demographic Transition." in Russia's Demographic "Crisis", edited by Julie Da Vanzo. RAND Center for Russia and Eurasia.

Zakharov, Sergei V. 1999. "Unlike their parents, the Russian youth are less eager to form families at young ages." in Second Workshop on Lowest Low Fertility, edited by Max Plank Institute for Demographic Research. unpublished draft.

Zakharov, Sergei V., Anatoly G. Vishnevskii, and Sakevich, V. I. 2005. "Brachnost i rozhdaemost (Marriage and fertility)” in Naselenie Rossii (Population of Russia), edited by Anatoly G. Vishnevskii.

Zakharov, Sergei V. 2008. "The First and Second Demographic Transition in Russia: Recent trends in the context of historic experience." in "Childbearing Trends and Policies: Country Case Studies", edited by Tomas Frejka, et al. 
Table 1. Distribution of first births by education, period, and union status

Less than secondary

\begin{tabular}{lcccc}
\hline & Single & Cohabiting & Married & N births \\
$1980-83$ & $23 \%$ & $15 \%$ & $62 \%$ & 47 \\
$1984-87$ & $24 \%$ & $22 \%$ & $54 \%$ & 46 \\
$1988-91$ & $19 \%$ & $17 \%$ & $64 \%$ & 69 \\
$1992-95$ & $18 \%$ & $22 \%$ & $60 \%$ & 50 \\
$1996-99$ & $28 \%$ & $15 \%$ & $58 \%$ & 40 \\
$2000-03$ & $22 \%$ & $22 \%$ & $56 \%$ & 41
\end{tabular}

Secondary (including lower vocational)

\begin{tabular}{|c|c|c|c|c|}
\hline & Single & Cohabiting & Married & $\mathrm{N}$ births \\
\hline 1980-83 & $9 \%$ & $6 \%$ & $85 \%$ & 391 \\
\hline $1984-87$ & $7 \%$ & $10 \%$ & $83 \%$ & 340 \\
\hline $1988-91$ & $11 \%$ & $10 \%$ & $78 \%$ & 353 \\
\hline 1992-95 & $10 \%$ & $11 \%$ & $79 \%$ & 253 \\
\hline 1996-99 & $7 \%$ & $17 \%$ & $76 \%$ & 225 \\
\hline 2000-03 & $14 \%$ & $17 \%$ & $68 \%$ & 202 \\
\hline \multicolumn{5}{|c|}{ Post-secondary (specialized secondary and university) } \\
\hline & Single & Cohabiting & Married & $\mathrm{N}$ births \\
\hline 1980-83 & $9 \%$ & $7 \%$ & $84 \%$ & 135 \\
\hline $1984-87$ & $9 \%$ & $11 \%$ & $80 \%$ & 137 \\
\hline 1988-91 & $13 \%$ & $12 \%$ & $75 \%$ & 113 \\
\hline 1992-95 & $14 \%$ & $11 \%$ & $75 \%$ & 106 \\
\hline 1996-99 & $17 \%$ & $17 \%$ & $66 \%$ & 64 \\
\hline
\end{tabular}

Source: Russian GGS. 
Table 2. Odds ratios from discrete-time hazard models of first conception rates: separate estimates for each union status

\begin{tabular}{|c|c|c|c|}
\hline & $\begin{array}{l}\text { Married } \\
\text { women }\end{array}$ & $\begin{array}{l}\text { Cohabiting } \\
\text { women }\end{array}$ & $\begin{array}{l}\text { Single } \\
\text { women }\end{array}$ \\
\hline Less than second. & $\begin{array}{l}0.792^{*} \\
(-2.13)\end{array}$ & & \\
\hline $\begin{array}{l}\text { Semi-profess. \& } \\
\text { university } \\
\text { Ref: Secondary }\end{array}$ & $\begin{array}{l}1.169 \\
(1.91)\end{array}$ & & $\begin{array}{l}0.640^{* *} \\
(-3.27)\end{array}$ \\
\hline $1980-83$ & $\begin{array}{c}1.634^{\star * \star} \\
(4.63)\end{array}$ & $\begin{array}{c}1.893^{\star \star \star} \\
(4.17)\end{array}$ & $\begin{array}{l}0.947 \\
(-0.39)\end{array}$ \\
\hline 1984-87 & $\begin{array}{c}1.780 * * * \\
(5.38)\end{array}$ & $\begin{array}{c}1.920 * \star * \\
(4.37)\end{array}$ & $\begin{array}{l}0.911 \\
(-0.65)\end{array}$ \\
\hline 1988-91 & $\begin{array}{c}1.864^{\star \star \star} \\
(5.67)\end{array}$ & $\begin{array}{c}1.744^{\star * \star} \\
(3.76)\end{array}$ & $\begin{array}{l}1.344^{*} \\
(2.13)\end{array}$ \\
\hline $1992-95$ & $\begin{array}{l}1.196 \\
(1.66)\end{array}$ & $\begin{array}{l}1.163 \\
(0.99)\end{array}$ & $\begin{array}{l}1.201 \\
(1.26)\end{array}$ \\
\hline Ref: 1996-99 & & & \\
\hline $2000-03$ & $\begin{array}{l}1.053 \\
(0.43)\end{array}$ & $\begin{array}{c}0.818 \\
(-1.40)\end{array}$ & $\begin{array}{c}0.915 \\
(-0.57)\end{array}$ \\
\hline School enrollment & $\begin{array}{l}1.071 \\
(0.99)\end{array}$ & $\begin{array}{c}0.604^{\star \star \star} \\
(-4.95)\end{array}$ & $\begin{array}{r}0.497^{\star \star \star} \\
(-6.83)\end{array}$ \\
\hline Age & $\begin{array}{l}0.863^{\star} \\
(-2.35)\end{array}$ & $\begin{array}{l}1.018 \\
(0.59)\end{array}$ & $\begin{array}{c}1.556^{\star \star \star *} \\
(8.98)\end{array}$ \\
\hline Age-squared & $\begin{array}{l}1.011 \\
(1.95)\end{array}$ & $\begin{array}{c}0.996 * \star \star \\
(-3.46)\end{array}$ & $\begin{array}{c}0.967^{\star \star \star *} \\
(-7.15)\end{array}$ \\
\hline Age-cubed & $\begin{array}{c}0.999633^{\star *} \\
(-2.60)\end{array}$ & & $\begin{array}{c}1.001^{\star \star \star *} \\
(4.51)\end{array}$ \\
\hline Duration in union & $\begin{array}{l}0.945^{\star \star \star} \\
(-11.94)\end{array}$ & $\begin{array}{c}0.965^{\star \star \star} \\
(-9.19)\end{array}$ & \\
\hline $\begin{array}{l}\text { Duration in union } \\
\text {-squared }\end{array}$ & $\begin{array}{l}1.000482^{\star \star \star} \\
(5.76)\end{array}$ & $\begin{array}{c}1.000 * * * \\
(6.20)\end{array}$ & \\
\hline $\begin{array}{l}\text { Duration in union } \\
\text {-cubed }\end{array}$ & $\begin{array}{l}0.999998^{\star \star \star} \\
(-4.11)\end{array}$ & & \\
\hline $\begin{array}{l}\text { Duration in Union } x \\
\text { post-1991 }\end{array}$ & $\begin{array}{c}1.010^{\star \star *} \\
(4.57)\end{array}$ & & \\
\hline$P$ & 15 & $8.48 e-79$ & $2.61 \mathrm{e}-60$ \\
\hline $\begin{array}{l}\text { Rank } \\
N\end{array}$ & 51890 & $\begin{array}{c}11 \\
23662\end{array}$ & $\begin{array}{c}11 \\
247140\end{array}$ \\
\hline
\end{tabular}

Note: Numbers in parentheses are t-statistics.

Source: Russian GGS.

${ }^{*} \mathrm{p}<.05{ }^{* \star} \mathrm{p}<.01{ }^{* \star \star} \mathrm{p}<.001$ (one-tailed tests) 
Appendix Table A: Odds ratios of competing risk hazard model of union status at first birth with three outcomes: single, cohabiting, and married

\begin{tabular}{|c|c|c|c|}
\hline & Single & Cohabiting & Marital \\
\hline Less than sec & $\begin{array}{l}1.417 \\
(1.89)\end{array}$ & $\begin{array}{c}0.910 \\
(-0.50)\end{array}$ & $\begin{array}{c}0.399^{* * *} \\
(-9.43)\end{array}$ \\
\hline Post-secondary & $\begin{array}{l}0.741^{*} \\
(-2.02)\end{array}$ & $\begin{array}{c}0.572^{\star * *} \\
(-3.77)\end{array}$ & $\begin{array}{c}0.894 \\
(-1.76)\end{array}$ \\
\hline 1980-83 & $\begin{array}{l}1.075 \\
(0.35)\end{array}$ & $\begin{array}{c}0.490 \star \star \star \\
(-3.44)\end{array}$ & $\begin{array}{c}1.398^{\star \star *} \\
(4.18)\end{array}$ \\
\hline 1984-87 & $\begin{array}{c}0.958 \\
(-0.20)\end{array}$ & $\begin{array}{c}0.792 \\
(-1.25)\end{array}$ & $\begin{array}{c}1.361^{\star \star *} \\
(3.75)\end{array}$ \\
\hline 1988-91 & $\begin{array}{l}1.647^{*} \\
(2.46)\end{array}$ & $\begin{array}{c}0.996 \\
(-0.02)\end{array}$ & $\begin{array}{c}1.646^{\star \star *} \\
(6.05)\end{array}$ \\
\hline 1992-95 & $\begin{array}{l}1.341 \\
(1.35)\end{array}$ & $\begin{array}{c}0.943 \\
(-0.31)\end{array}$ & $\begin{array}{c}1.392^{\star * \star} \\
(3.80)\end{array}$ \\
\hline \multicolumn{4}{|l|}{ Ref: 1996-99 } \\
\hline 2000-03 & $\begin{array}{l}1.492 \\
(1.92)\end{array}$ & $\begin{array}{l}1.074 \\
(0.39)\end{array}$ & $\begin{array}{l}1.044 \\
(0.47)\end{array}$ \\
\hline $\begin{array}{l}\text { School } \\
\text { enrollment }\end{array}$ & $\begin{array}{c}0.387^{\star \star *} \\
(-6.22)\end{array}$ & $\begin{array}{c}0.302^{\star \star \star} \\
(-8.13)\end{array}$ & $\begin{array}{c}0.741^{\star \star \star} \\
(-5.20)\end{array}$ \\
\hline Age & $\begin{array}{c}1.985^{\star \star *} \\
(6.70)\end{array}$ & $\begin{array}{c}1.641^{\star * *} \\
(5.40)\end{array}$ & $\begin{array}{c}2.388^{\star * *} \\
(15.71)\end{array}$ \\
\hline Age-squared & $\begin{array}{c}0.987^{\star \star \star} \\
(-6.97) \\
\end{array}$ & $\begin{array}{c}0.990^{\star \star \star} \\
(-5.90)\end{array}$ & $\begin{array}{l}0.983^{\star \star \star} \\
(-16.34)\end{array}$ \\
\hline$p$ & 0 & & \\
\hline rank & 33 & & \\
\hline $\mathrm{N}$ & 343303 & & \\
\hline
\end{tabular}

Note: Numbers in parentheses are t-statistics.

Source: Russian GGS.

${ }^{*} \mathrm{p}<.05^{* *} \mathrm{p}<.01{ }^{* * \star} \mathrm{p}<.001$ (one-tailed tests) 
Appendix Table B. Multinomial Logit Model odds ratios for union status at birth for conceptions that occurred to single or cohabiting women. Reference category for each MLM is married at birth

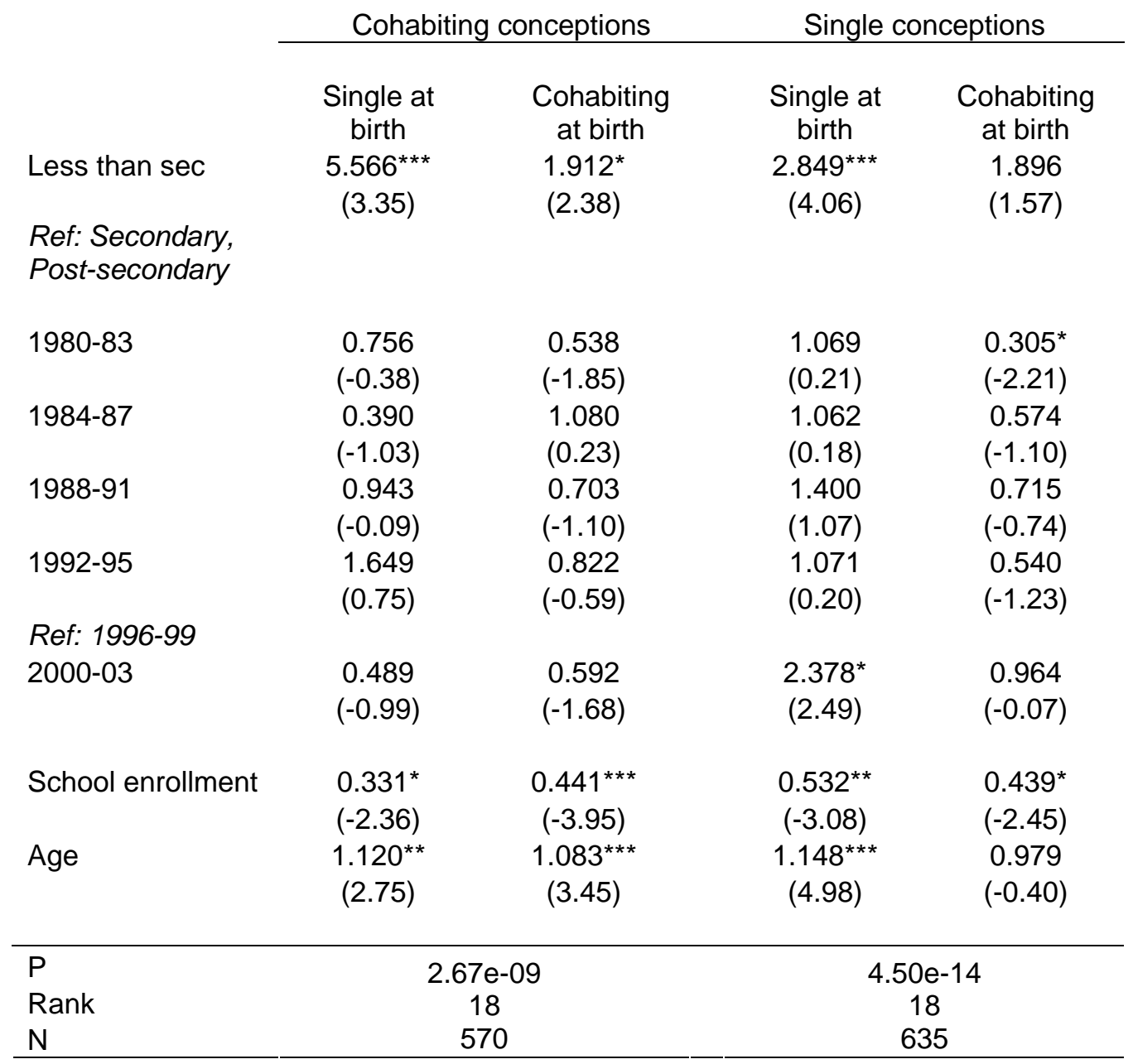

Note: Numbers in parentheses are t-statistics.

Source: Russian GGS.

${ }^{*} \mathrm{p}<.05{ }^{* *} \mathrm{p}<.01{ }^{* * *} \mathrm{p}<.001$ (one-tailed tests) 
Figure 1. Stylized multi-state model for first births, by union status

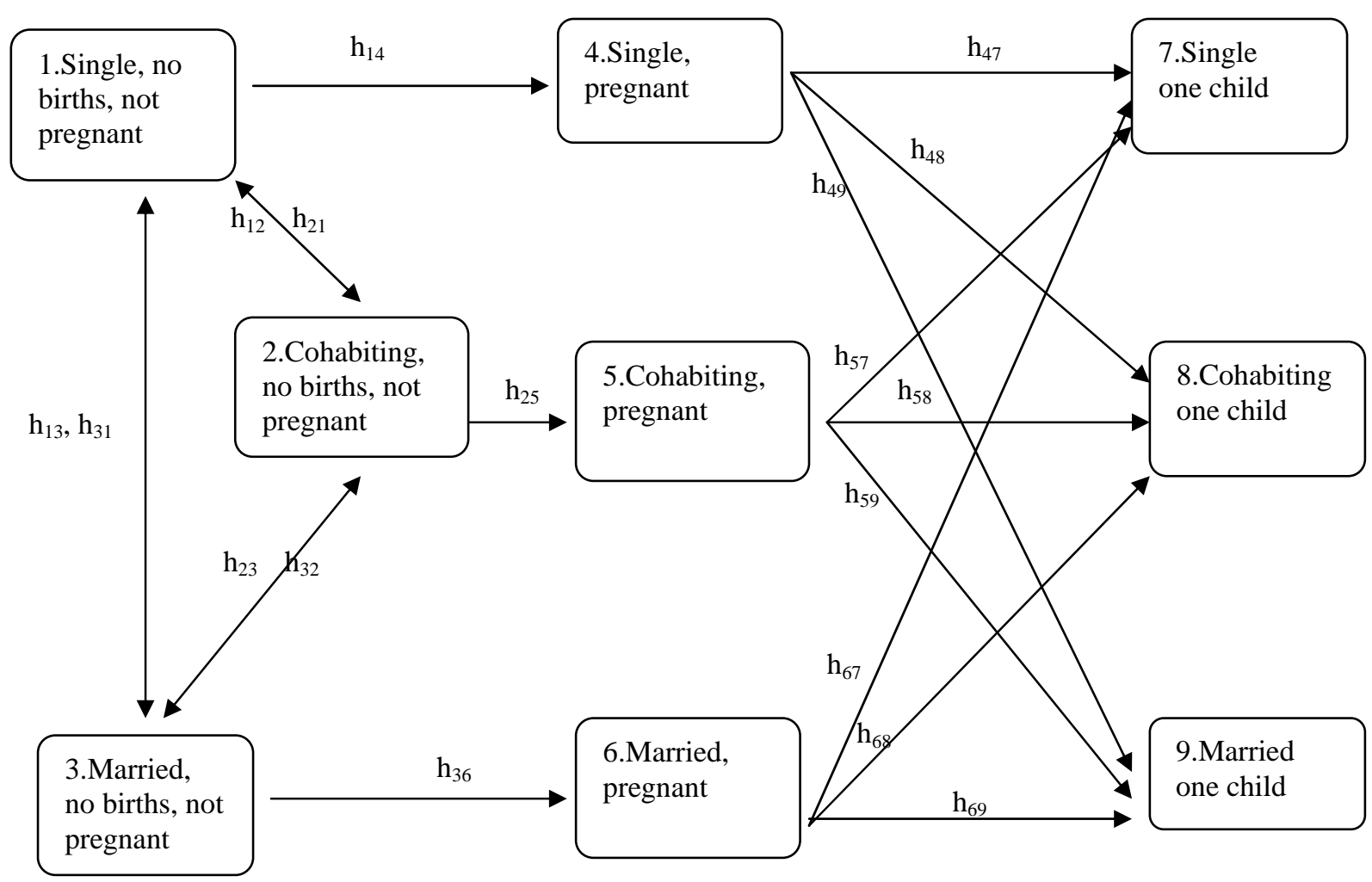

Note: For simplicity, we assume all conceptions lead to births (no abortions or miscarriages). See text for further explanations. 
Figure 2. Percent distribution of first births by marital status and period

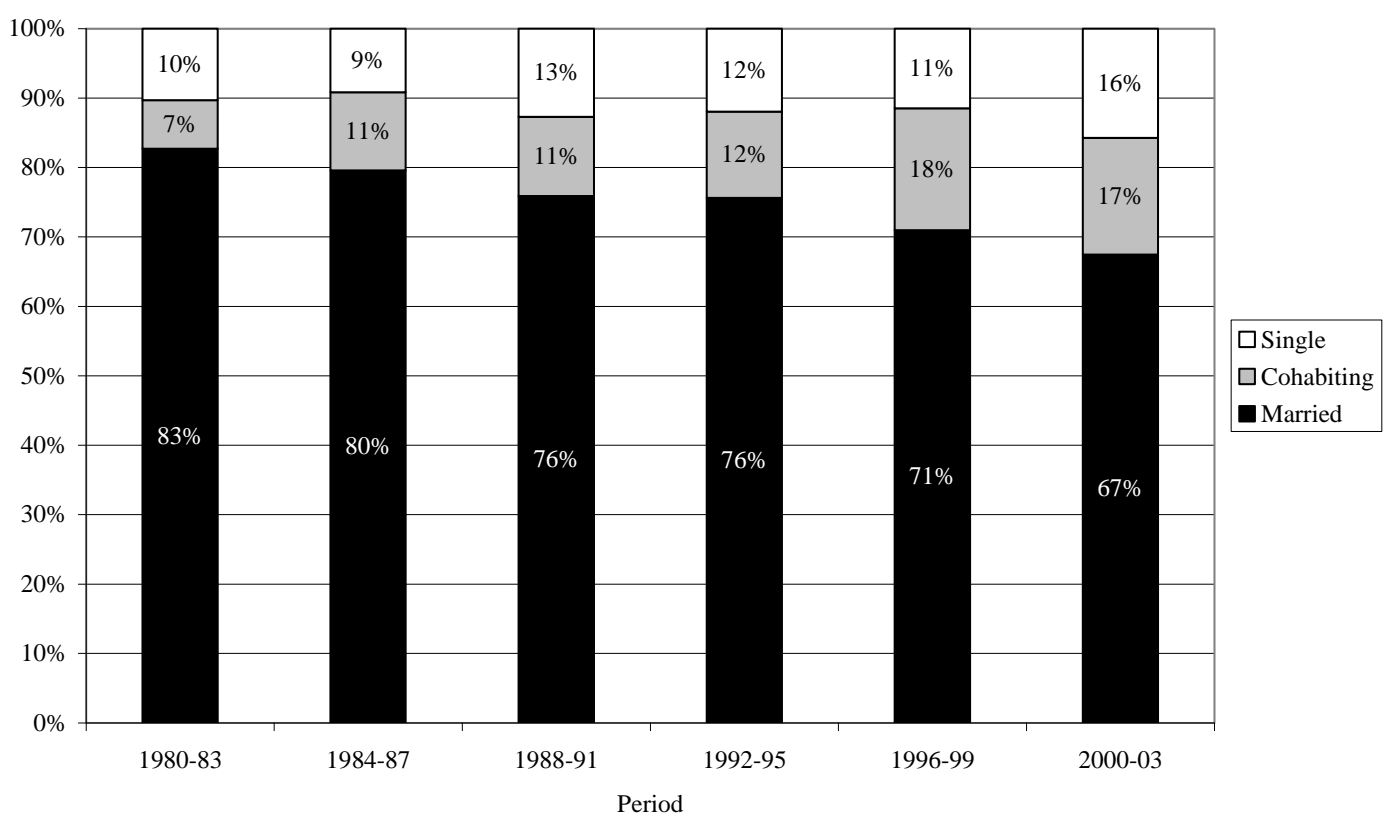

Source: Russian GGS. 
Figure 3. Predicted hazards of single, cohabiting, and marital first births, adjusted only for age (estimated at age 22)

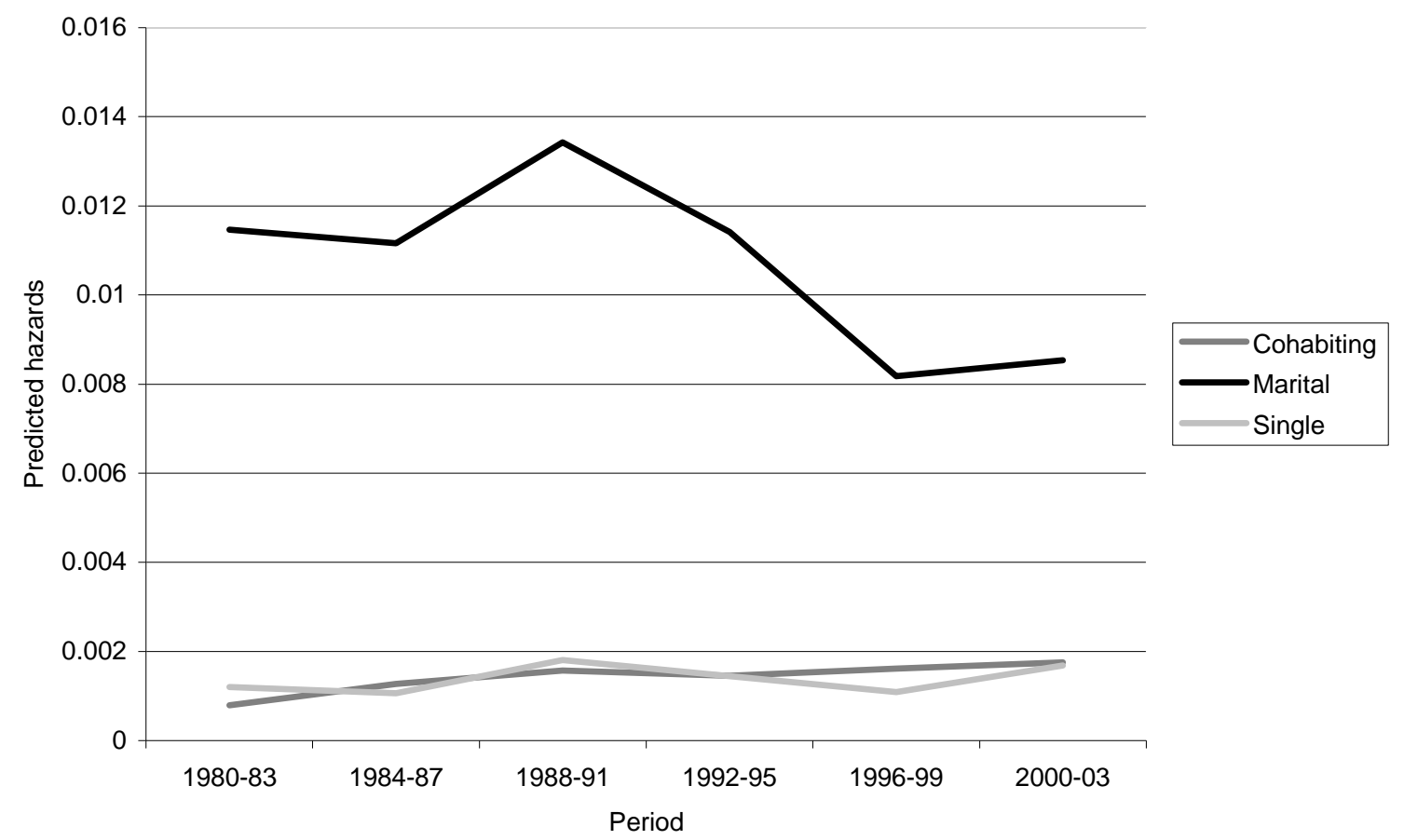

Source: Russian GGS. 
Figure 4. Predicted first birth hazards by union status and level of education, adjusted for age (estimated at age 22)

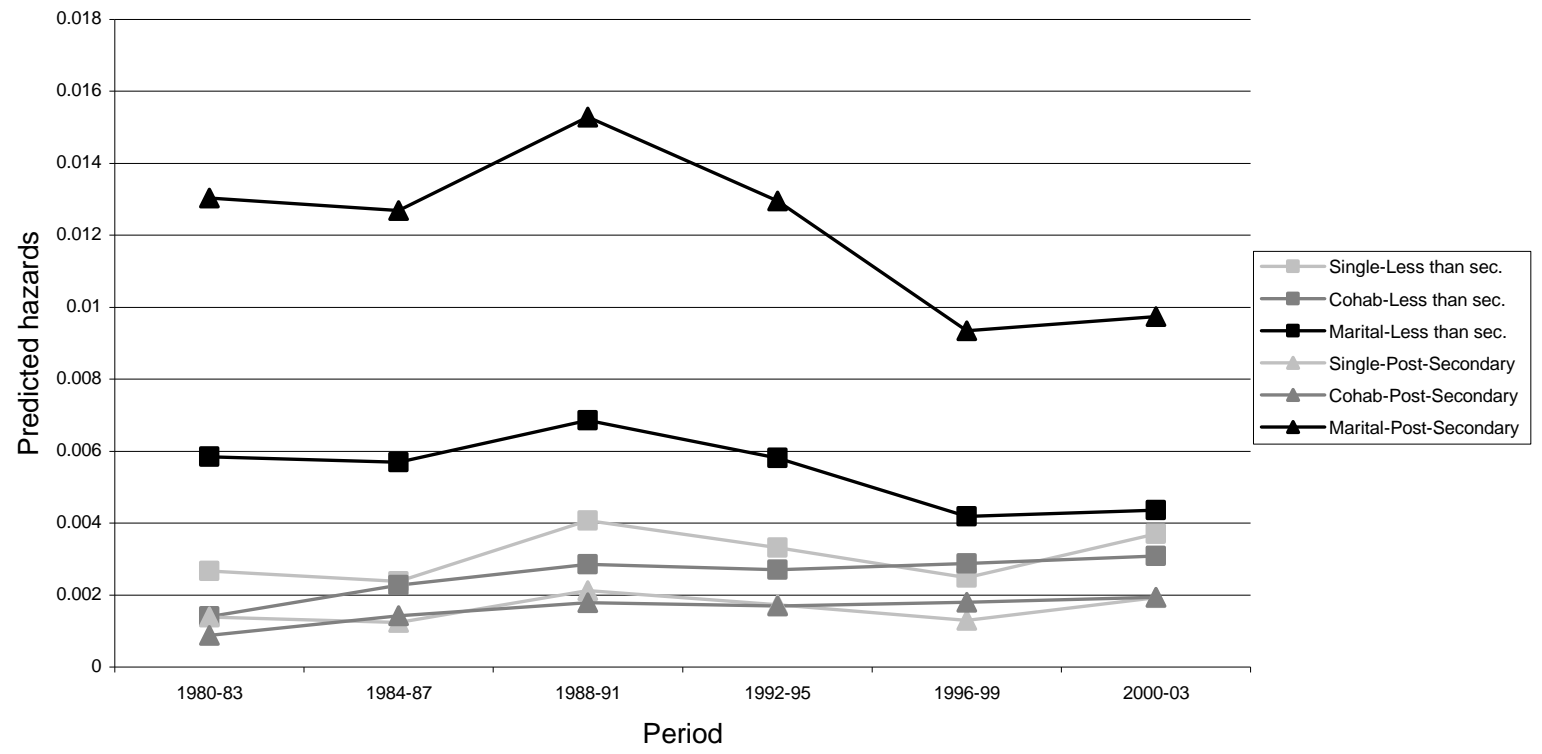

Source: Russian GGS. 
Figure 5. Predicted hazards of first conception in cohabitation and marriage by union duration for 1980 and 2000 (Estimated from results in Table 2 at age 22 and secondary degree)

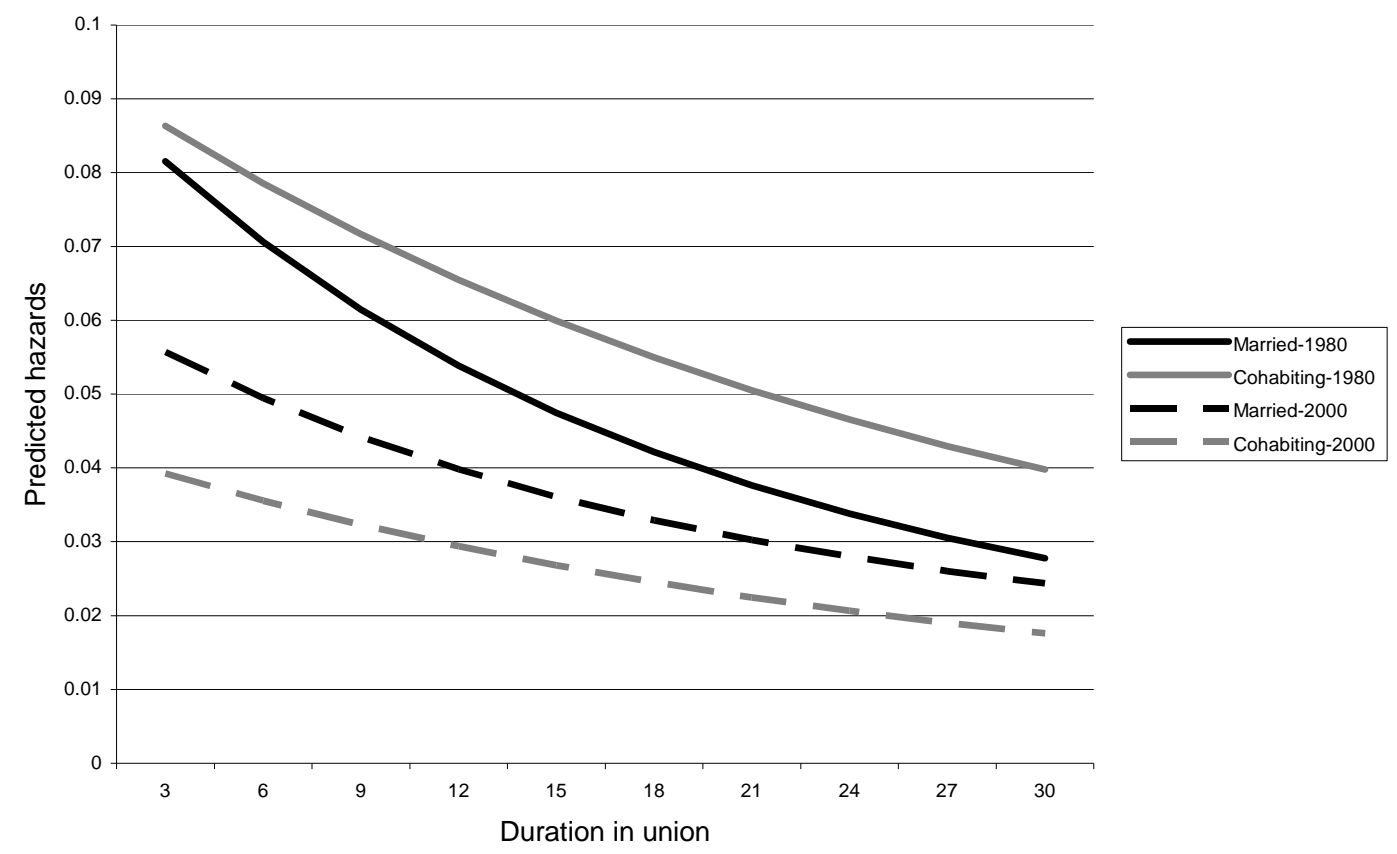

Source: Russian GGS. 
Figure 6. Predicted percentage of single and cohabiting conceptions that result in each union status at birth (estimated at age 22, secondary degree)

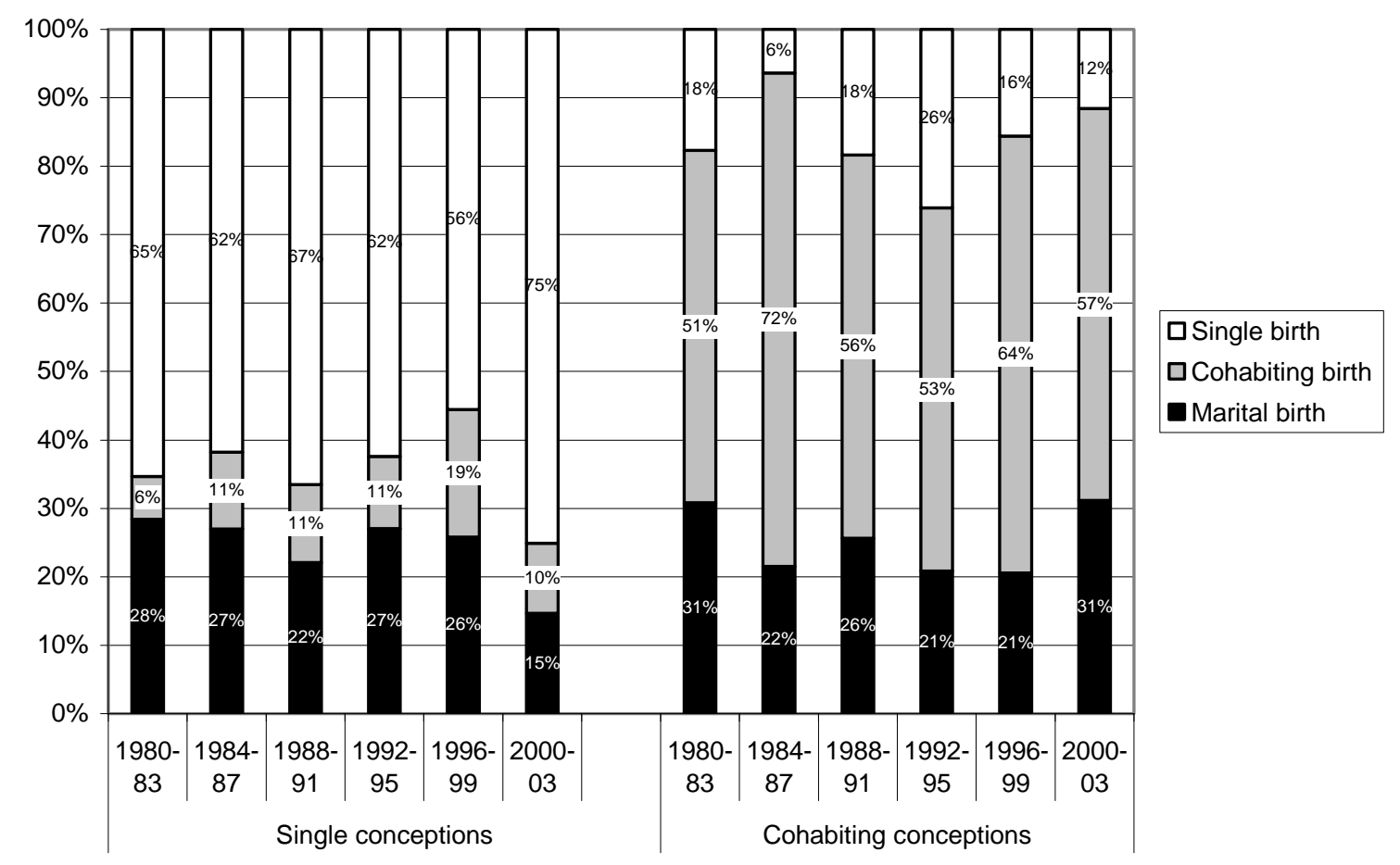

Source: Russian GGS. 
Figure 7. Predicted probabilities of union status at first birth for women single and cohabiting at conception, by education (Estimated at age 22, 1996-1999)

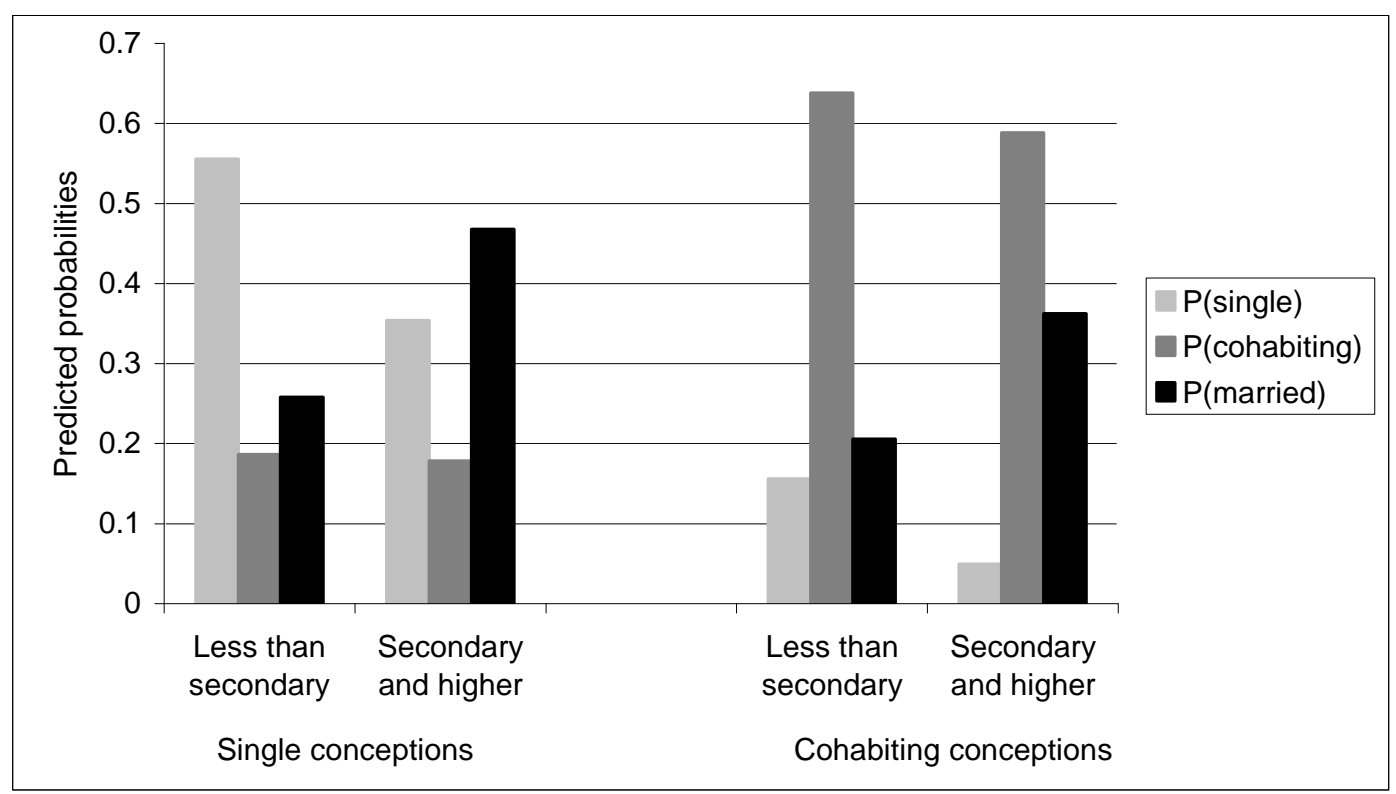

Source: Russian GGS. 
Figure 8. Distribution of childless women aged 15-49 by union status in December of each year

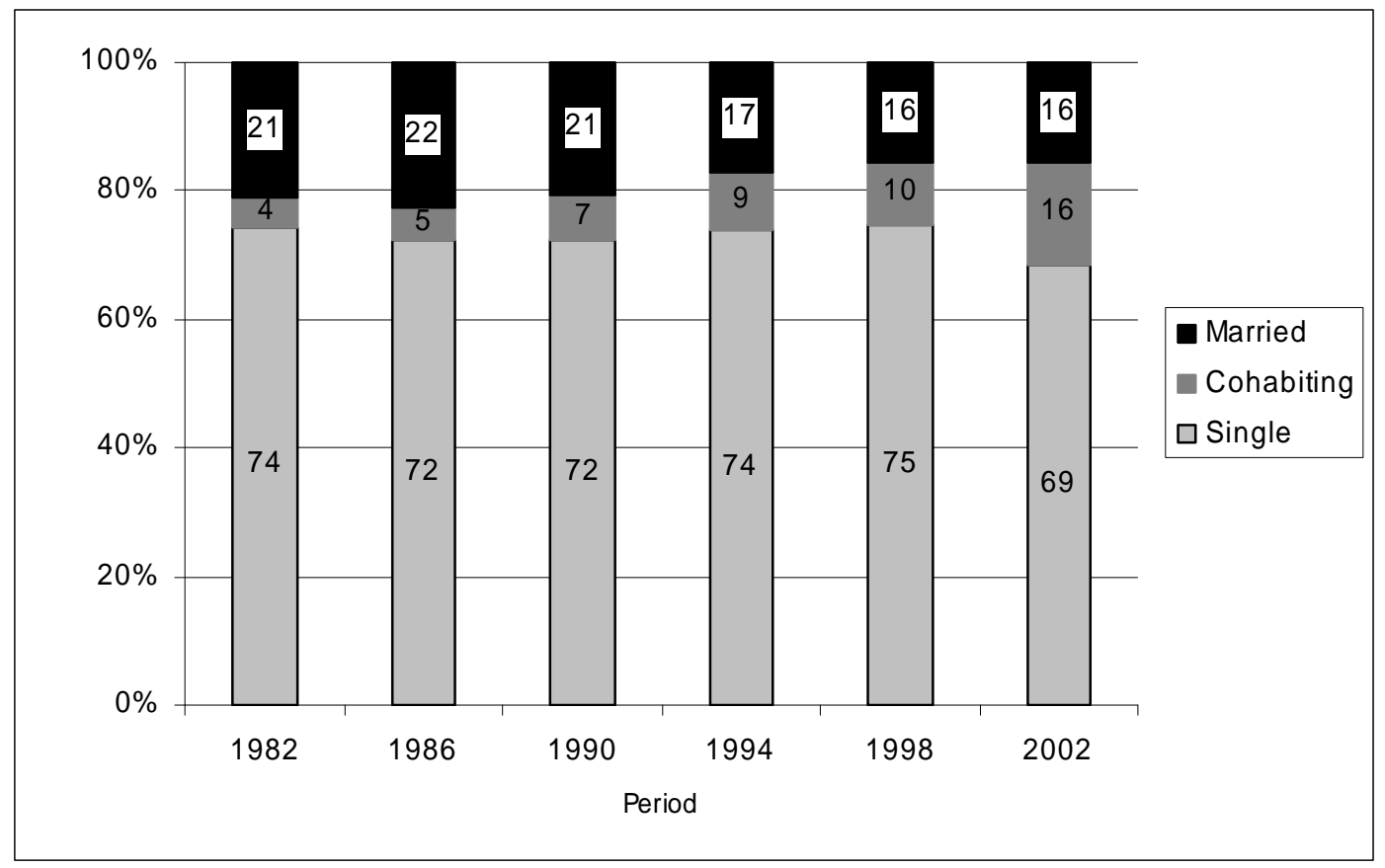

Source: Russian GGS. 